\title{
Nuclear translocation of MRTFA in MCF7 breast cancer cells shifts ERa nuclear/genomic to extra-nuclear/non genomic actions
}

Charly Jehanno ${ }^{\mathrm{a}, \mathrm{b}}$, Frédéric Percevault ${ }^{\mathrm{a}}$, Noureddine Boujrad ${ }^{\mathrm{a}}$, Pascale Le Goff ${ }^{\mathrm{a}}$, Coralie Fontaine ${ }^{\mathrm{c}}$, Jean-François Arnalc ${ }^{c}$, Michael Primiga ${ }^{a}$,Farzad Pakdel ${ }^{a}$, Denis Michela ${ }^{a}$, Raphaël Métivier ${ }^{\mathrm{d}}$ and Gilles Flouriot $\mathrm{a}^{\mathrm{a}}$

aUniv Rennes, Inserm, EHESP, Irset (Institut de Recherche en Santé, Environnement et Travail) UMR_S 1085, F-35000 Rennes, France

bUniversity Hospital Basel, University of Basel, Basel, Switzerland

'INSERM U1048, Institut des Maladies Métaboliques et Cardiovasculaires, Université de Toulouse - UPS, Toulouse, France

d Univ Rennes, Institut de Génétique et Développement de Rennes, UMR 6290 CNRS, Rennes, France

*To whom correspondence should be addressed. Tel: +33-2 232368 04; Fax: +33-2 232367 94;

Email: gilles.flouriot@univ-rennes1.fr

Running Title: MRTFA favors non-genomic activity of ER $\alpha$

Keywords: Breast cancer, Endocrine resistance, Estrogen receptor, MRTFA, P160 family coactivators, NCOR1, SMRT, PI3K, src, 


\begin{abstract}
The Myocardin-related transcription factor A [MRTFA, also known as Megakaryoblastic Leukemia 1 (MKL1))] is a major actor in the epithelial to mesenchymal transition (EMT). We have previously shown that activation and nuclear accumulation of MRTFA mediate endocrine resistance of estrogen receptor alpha $(E R \alpha)$ positive breast cancers by initiating a partial transition from luminal to basal-like phenotype and impairing ERa cistrome and transcriptome. In the present study, we deepen our understanding of the mechanism by monitoring functional changes in the receptor's activity. We demonstrate that MRTFA nuclear accumulation down-regulates the expression of the unliganded (Apo-)ER $\alpha$ and causes a redistribution of the protein localization from its normal nuclear place to the entire cell volume. This phenomenon is accompanied by a shift in Apo-ERa monomer/dimer ratio towards the monomeric state, leading to significant functional consequences on ERa activities. In particular, the association of Apo-ERa with chromatin is drastically decreased, and the remaining ERa binding sites are substantially less enriched in ERE motifs than in control conditions. Monitored by proximity Ligation Assay, ERa interactions with P160 family coactivators are partly impacted when MRTFA accumulates in the nucleus, and those with SMRT and NCOR1 corepressors are abolished. Finally, ER $\alpha$ interactions with kinases such as c-src and PI3K are increased, thereby enhancing MAP Kinase and AKT activities. In conclusion, the activation and nuclear accumulation of MRTFA in ER $\alpha$ positive breast cancer cells remodels both ERa location and functions by shifting its activity from nuclear genome regulation to extra-nuclear non-genomic signaling.
\end{abstract}




\section{Introduction}

Mediating estradiol $\left(E_{2}\right)$ signaling, the estrogen receptor-alpha $(E R \alpha)$ is central in controlling proliferation of epithelial mammary cells and is therefore intimately associated with the onset of breast cancers (Couse and Korach, 1999). More than two-thirds of primary breast tumors are ER $\alpha$-positive and exhibit $\mathrm{E}_{2}$-dependent growth (Dahlman-Wright et al., 2006; Platet et al., 2004). These tumors define the luminal breast cancer subtypes that are distinct from HER2enriched and basal-like tumor subtypes (Perou et al., 2000; Sørlie et al., 2001). Luminal subtypes are more differentiated and less invasive than the other subtypes and in general initially respond well to endocrine therapy (Osborne, 1998). Unfortunately, tumors eventually acquire resistance and become unresponsive to hormonal therapy (Clarke et al., 2015; Jordan and O'Malley, 2007). Escape of proliferation to hormonal control enables tumor cells to undergo invasive and metastatic processes that are associated with an unfavorable vital prognosis. A better understanding of molecular mechanisms underlying hormonal resistance is thus critical for designing effective treatments that lower the rate of cancer relapse or tumor recurrence.

$\mathrm{ER} \alpha$ is a ligand-inducible transcription factor that belongs to the nuclear receptor superfamily (Evans, 1988). ER $\alpha$ regulates gene expression upon binding to regulatory sequences, either directly through the association of an ER $\alpha$ dimer with palindromic DNA target sequences called estrogen responsive element (ERE), or indirectly through protein-protein interactions with other transcriptional regulators (Beato, 1989). Recent developments in chromatin immunoprecipitation and DNA high-throughput sequencing (ChIP-Seq) allowed for the identification of the ER $\alpha$ cistrome in several ER $\alpha$-positive breast cancer cell lines such as MCF7, for which the genome contains 5,000 to 10,000 ER $\alpha$ binding sites (ERBSs), 75\% of which containing EREs (Carroll et al., 2006; Stender et al., 2010). ER $\alpha$ recruits co-activators or corepressors in an ordered, cyclical and combinatorial process leading to transcriptional activation or repression of its target genes (Métivier et al., 2003). In addition to the so-called genomic regulatory activity as a DNA binding transcriptional regulator, ER $\alpha$ also associates with the plasma membrane where it responds to many signal transduction pathways, including MAP kinase (MAPK) and phosphatidyl-inositol 3-kinase (PI3K) signaling (Edwards, 2005a). The rapid signaling activity of $\mathrm{ER} \alpha$ can ultimately result in the regulation of gene expression, thereby highlighting the complex interrelationship between membrane and nuclear events (Arnal et al., 2017).

Tumors status regarding ER $\alpha$ relies on mechanisms that are established during endocrine resistance. In the majority of endocrine resistant breast cancers ER $\alpha$ continues to be highly expressed when they become resistant to hormone therapy. This phenomenon is based on an adaptation of the functional properties of $\mathrm{ER} \alpha$ from ligand-dependent activities to ligandindependent activities, which renders the receptor insensitive to anti-estrogens (Clarke et al., 2015; Jordan and O'Malley, 2007). Tumors remain, however, associated with a luminal breast cancer subtype. The loss of ER $\alpha$ expression, observed in almost $30 \%$ of endocrine resistant breast cancers, is associated with cancers shifting from luminal to basal-like cancer subtypes and a more adverse prognosis (Kuukasjärvi et al., 1996). We have recently shown that MRTFA (MKL1) in estrogen sensitive breast cancer cells triggers epithelial to mesenchymal transition (EMT) with a partial luminal to basal-like phenotype transition that leads to endocrine resistance (Jehanno et al., 2020; Kerdivel et al., 2014). MRTFA is a master regulator of actin polymerisation and cellular motility functions in many processes (Pipes et al., 2006). MRTFA also functions as a coactivator of the serum response factor (SRF) whose activity is regulated by the level of actin polymerization (Miralles et al., 2003). MRTFA is sequestered in an inactive form in the cytoplasm, but when G actin polymerises into filamentous (F) actin MRTFA translocates into the nucleus. In breast tissue, the protein's activity is restricted to basal/myoepithelial breast cells responsible for milk ejection during lactation (Sun et al., 2006). MRTFA expression was shown to promote tumor cell invasion and metastasis during malignant transformation (Medjkane et al., 2009). Its locus was recently 
identified by genome-wide association studies as a susceptibility risk factor for triple-negative breast cancers (Gurbuz et al., 2014; Lindström et al., 2014; Purrington et al., 2014). Corroborating these data, we recently demonstrated that the nuclear translocation of MRTFA is associated with endocrine resistance in a cohort of breast cancers (Jehanno et al., 2020). Following nuclear accumulation of MRTFA in luminal ER $\alpha$ positive breast cancer cells, estrogen signaling is impaired by a massive loss of ER $\alpha$ binding sites (ERBSs) on chromatin, associated with lower ER $\alpha$-binding activity. The estrogen-dependent regulation of gene expression is almost entirely abolished (Jehanno et al., 2020). In the present study, we elucidate molecular aspects of functional changes in ER $\alpha$ activity that occur during MRTFA-induced EMT of breast cancer cells. We demonstrate that the decline of ER $\alpha$ 's genomic DNA-mediated regulatory activity during the dedifferentiation process is accompanied by a dramatic increase of its non-genomic membrane-associated signaling activity. This is in part due to a relocation of unliganded (Apo)-ER $\alpha$ protein from the nucleus to the entire cell volume and a displacement of its monomer/dimer ratio towards its monomer state. 


\section{Material and methods}

\subsection{Cell culture and transfection}

Stably transfected MCF7 T-Rex sub-clones (T-Rex system, Invitrogen), control MCF7 (with empty pcDNAA/TO expression vector) and MRTFA- $\Delta$ N200 MCF7 (with MRTFA- $\Delta$ N200 pcDNA4/TO expression vector), were previously described (Flouriot et al., 2014; Kerdivel et al., 2014). In MRTFA- $\Delta$ N200 pcDNA4/TO expression vector, MRTFA- $\Delta$ N200 was fused to flag epitope. MCF7 and T47D cells were routinely maintained in DMEM (Invitrogen) supplemented with $10 \%$ fetal calf serum (FCS) (Biowest) and antibiotics (Invitrogen) at $37^{\circ} \mathrm{C}$ in $5 \% \mathrm{CO}_{2}$. Before any experiments, cells were grown in phenol red-free DMEM (Invitrogen) containing 2.5\% charcoal-stripped FCS (Biowest) for at least 72 hours. To induce expression of the constitutively active mutant of MRTFA (MRTFA- $\Delta$ N200), cells were treated for 48 hours with $1 \mu \mathrm{g} / \mathrm{mL}$ tetracycline before harvesting. 17 $\beta$-estradiol (E2, Sigma-Aldrich), ICI 182,780 (ICI, Sigma-Aldrish) and 4-hydroxytamoxifen (OHT, Sigma-Aldrish) were used at a final concentration of $10 \mathrm{nM}, 100 \mathrm{nM}$ and $1000 \mathrm{nM}$, respectively. Jasplakinolide (Abcam) was used at the final concentration of $0.5 \mu \mathrm{g} / \mathrm{ml}$. Transfection of siRNA (Mission siRNA, Sigma-Aldrich) was performed using jetPRIME transfection reagent according to manufacturer's instructions (Polyplus).

\subsection{RT-PCR assays}

Quantitative RT-PCRs were performed as previously described (Kerdivel et al., 2014).

\subsection{Protein extraction and Western blotting}

Subcellular fractionation was performed as previously described (Penot et al., 2005). Whole-cell extracts were directly prepared in $3 \mathrm{X}$ Laemmli buffer. Following sonication, the protein extracts were denatured for five minutes at $95^{\circ} \mathrm{C}$, separated on $10 \%$ SDS polyacrylamide gels and transferred to polyvinylidene difluoride membranes (Millipore). The proteins were then probed with specific antibodies. Antibodies used were against MRTFA (ab14984, Abcam), flag (M2, SigmaAldrish), phospho ERK (pERK) (sc-sc-7383, Santa Cruz Biotechnology), ERK1 (sc-94, Santa Cruz Biotechnology), phospho AKT (pAKT) (CS4060, cell Signaling), AKT (CS9272, Cell Signaling), ER $\alpha$ (sc-543, Santa Cruz Biotechnology), HSP70 (ab2287, Abcam), $\alpha$ tubulin (sc-8035, Santa Cruz Biotechnology), lamin A/C (ab40567, Abcam) and $\beta$ actin (A1978, Sigma-Aldrish). An enhanced chemiluminescence system (Immune-Star, Bio-Rad) was used to the detect immunocomplexes.

\subsection{Immunofluorescence}

Cells were grown on $10 \mathrm{~mm}$-diameter coverslips in 24-well plates. After treatment, cells were fixed with phosphate-buffered saline (PBS) containing 4\% paraformaldehyde (PAF) for 10 minutes and then permeabilized in PBS containing $0.3 \%$ Triton X-100 for 10 minutes. Incubation with the primary antibody $(1 / 1000)$ was performed overnight at $4^{\circ} \mathrm{C}$. Primary antibodies against ER $\alpha$ (HC20, sc-543) and c-src (B-12, sc-8056) were purchased from Santa Cruz Biotechnology. Antibodies directed against MRTFA (ab14984), PI3kinase P85 alpha (ab22653), MRTFA (ab14984), SRC1 (ab84), SRC3 (ab2782) and HSP70 (ab2287) were obtained from Abcam. Antibodies directed against NCOR1 (MA5-15447) and SMRT (MA1-B43) were obtained from Invitrogen. Dyeconjugated secondary antibodies (Abcam) were incubated for one hour at room temperature. The cover slides were mounted in Duolink II mounting medium with DAPI (Sigma-Aldrich), images were obtained with an ApoTome Axio Z1 Imager microscope (Zeiss) and processed with Axio Vision Software. Fluorescence was quantified with ImageJ software from images obtained with 
identical exposure times. Immunofluorescence was scored for at least 20 cells per image on $n$ images obtained from diverse experiments. The means obtained for every image were then averaged.

\subsection{Proximity Ligation Assay}

The proximity Ligation Assay (PLA) (Duolink, Sigma-Aldrich) was used to detect ER $\alpha$ interaction with different partners and ER $\alpha$ homodimers, according to manufacturer's instructions. Briefly, to measure ER $\alpha$ interaction with a given partner, MCF7 and T47D cells were plated, fixed and incubated with the corresponding primary antibodies as previously described in the immunofluorescence section. After washing, cells were incubated one hour at $37^{\circ} \mathrm{C}$ in a humidity chamber with PLA MINUS and PLUS probes conjugated with complementary oligonucleotides, followed by a ligation step of the oligonucleotides during 30 minutes and a rolling-circle amplification (RCA) reaction using the ligated circle as a template, in which fluorescently labeled oligonucleotides were hybridized to the RCA product. The cover slides were mounted in Duolink II mounting medium with DAPI (Sigma-Aldrich). The images were obtained with an ApoTome Axio Z1 Imager microscope (Zeiss) and processed with Axio Vision Software. PLA dots were analyzed using ImageJ software. For the detection of ER $\alpha$ homodimers, we directly conjugated the PLA oligonucleotides MINUS and PLUS to an ER $\alpha$ monoclonal antibody (sp1, ab27595, Abcam) using the Duolink in situ probemaker kits (Sigma-Aldrich). The monoclonal antibody was first purified through protein A affinity and concentrated using a centrifugal filter concentrator. Through this process, MINUS and PLUS conjugated ER $\alpha$ antibodies recognize the same epitope, and the RCA can only take place if ER $\alpha$ is under a homodimer form. Red dots were scored for at least 20 cells by image on $n$ images obtained from diverse experiments. The means obtained for every image were then averaged.

\subsection{Saturation ligand binding assays}

Whole cell extracts were obtained by thawing-freezing cycles of MCF7 cells in WCE buffer (20 $\mathrm{mM}$ HEPES pH 7.9, $400 \mathrm{mM} \mathrm{KCl}, 2 \mathrm{mM}$ dithiothreitol and $20 \%$ glycerol). Tritium-radiolabeled estradiol binding studies were performed at $4{ }^{\circ} \mathrm{C}$ on $30 \mu \mathrm{g}$ of whole cell extracts using up to 12.5 $\mathrm{nM}$ of ${ }^{3} \mathrm{H}$-estradiol $\left({ }^{3} \mathrm{H}-\mathrm{E}_{2}\right)$. Nonspecific binding was determined in the presence of 150 -fold excess of unlabelled ligand. After overnight incubation at $4^{\circ} \mathrm{C}$, the assays were stopped by filtration through Whatman GF/C and washed with $10 \mathrm{ml}$ ice-cold PBS. The radioactivity trapped on the filters was determined by liquid scintillation counting at 30\% efficiency. Saturation isotherms for ${ }^{3} \mathrm{H}$-estradiol binding and Scatchard analysis were performed on three independent experiments.

\subsection{ChIP-seq data analysis}

Bioinformatic analyses of ER cistromes in control or MRTFA- $\triangle$ N200 expressing MCF7 cells were made using our previously published set of ChIP-seq data (GEO, GSE 107476) (Jehanno et al., 2020). Characteristics of ER binding sites in these cells were determined using custom-made scripts and algorithms from the cistrome web-platform (http://cistrome.org/ap/). Motifs analyses were performed using the CentDist website (http://biogpu.ddns.comp.nus.edu.sg/ chipseq/webseqtools2). 


\section{Results}

\subsection{Nuclear accumulation of MRTFA impacts subcellular localization and dimerization state equilibrium of Apo-ERa in MCF7 cells}

We have previously shown that MRTFA is mainly cytoplasmic and inactive in luminal ER $\alpha$ positive breast cancer cells, while it is nuclear and active in basal-like breast cancer cells having undergone an epithelial-mesenchymal transition (EMT) (Jehanno et al., 2020; Kerdivel et al., 2014). To study the consequences of a nuclear accumulation of MRTFA in luminal ER $\alpha$ positive breast cancer cells, we previously established a MCF7 cell line expressing a mutated form of MRTFA (MRTFA- $\Delta$ N200) devoid of its N-terminal actin binding sites, which allows a permanent translocation and a constitutive activity of MRTFA into the nucleus. Thanks to the T-Rex system, MRTFA- $\triangle$ N200 is produced in MCF7 cells after tetracycline treatment (see Fig. 1, A and B). Through this approach, we further demonstrated that nuclear translocation of MRTFA favored the commitment of hormone-dependent breast cancer cells towards EMT by inducing invasiveness (Jehanno et al., 2020; Kerdivel et al., 2014). In the present study, western blot analysis and immunofluorescence experiments showed that the expression level of Apo-ER $\alpha$ was reduced by 50$60 \%$ in MRTFA- $\triangle$ N200 MCF7 cells compared to untreated control MCF7 cells (Fig. 1, A and C). In addition, the remaining ER $\alpha$ relocated from the nucleus to the entire cell, partly depleting the nucleus of MRTFA- $\triangle$ N200 MCF7 cells from the receptor (Fig. 1, C and D). Nuclear translocation of MRTFA is favors by actin polymerization into F-actin (Miralles et al., 2003). Therefore, to confirm the changes in Apo-ER $\alpha$ expression and subcellular localization following MRTFA nuclear translocation, normal MCF7 cells were treated with jasplakinolide, a commonly used F-actin polymerization and stabilizing drug. Indeed, nuclear translocation of MRTFA in MCF7 cells induced by jasplakinolide treatment is accompanied by a decrease in ER $\alpha$ expression and a relocation of the protein at the cytoplasmic level. Similar results were observed with T47D, another luminal ER $\alpha$ positive breast cancer cell line (see Supplementary Fig. 1, C and D).

To further characterize whether ER $\alpha$ properties are changed in MCF7 cells expressing the mutant MRTFA protein, we performed a saturation $\left[{ }^{3} \mathrm{H}\right]$-E2 binding assay using whole cell extracts of control samples and MRTFA- $\triangle \mathrm{N} 200$ MCF7 cells. $\left[{ }^{3} \mathrm{H}\right]-\mathrm{E} 2$ binding was specific in both cell extracts, whereby three times more specific binding sites were recognized in control cells than MRTFA- $\triangle$ N200 MCF7 cells. This is in agreement with the ER $\alpha$ expression level assayed by Western blots and immunofluorescence experiments (Fig. 1). The equilibrium dissociation constants $\left(\mathrm{K}_{\mathrm{d}}\right)$ tended toward a common value $(0.4 \mathrm{nM})$ in both cell types. However, the Scatchard plot from MRTFA- $\triangle$ N200 MCF7 cells was almost linear, while the one from control MCF7 cells revealed a convex curve with a positive cooperativity (Fig. 1E, bottom panel). Such a phenomenon was previously shown to depend upon the monomer/dimer equilibrium of the binding element, E2 (Notides et al., 1981), thereby suggesting a disequilibrium in favor of ER $\alpha$ monomers in untreated MRTFA- $\triangle$ N200 MCF7 cells. To this end, we performed a proximity ligation assay (PLA) using a monoclonal ER $\alpha$ antibody directly conjugated to the MINUS and PLUS probes. Recognizing the same epitope, the two ER $\alpha$ probes interact together only if ER $\alpha$ is under a homodimer form, with one probe on each monomer. To validate the approach, we first established the relationship between the amounts of ER $\alpha$ homodimers assessed by PLA and the expression level of ER $\alpha$ measured by immunofluorescence in untreated and E2-treated control MCF7 cells (see Supplementary Fig. 2). Cells were classified according to the relative intensity of ER $\alpha$ staining, grouped into intensity bins. The number of dots per cell was then averaged for a given intensity bin. The results obtained demonstrated that the number of homodimer dots per cell is proportional to the ER $\alpha$ amount above a threshold level of receptor molecules. The threshold was 2-3 times lower in the presence of E2 than in its absence. This fold change was also in agreement with previous FRET-based studies measuring unliganded (Apo)- and liganded (Holo)- ER $\alpha$ homodimer affinity (Padron et al., 2007; 
Tamrazi et al., 2002). Further analysis of our PLA data showed that the homodimer dots were mainly nuclear in control cells $(80 \%)$, increasing more than two-fold after E2 treatment. On the contrary, they were distributed uniformly throughout the cells in MRTFA- $\triangle$ N200 MCF7 cells, and their numbers were reduced (Fig. 1F). Ultimately, to ensure that the expression of MRTFA- $\Delta$ N200 in MCF7 impacts the ER $\alpha$ monomer/dimer equilibrium, we extended our study by monitoring ER $\alpha$ interaction with HSP70 using the PLA approach. In the absence of E2, ER $\alpha$ monomers are thought to be associated with chaperone proteins such as HSP90 and HSP70 (Dhamad et al., 2016; Pratt and Toft, 1997). Dissociation from the chaperone complexes is induced by E2 and this process is a prerequisite for ER $\alpha$ dimerization. Western blot analysis of HSP70 expression indicates an accumulation of the chaperone in the nuclear fraction of MRTFA- $\triangle N 200$ MCF7 cells while the protein remained cytoplasmic in control cells (Fig. 1D). In addition, PLA results showed that ER $\alpha /$ HSP70 interactions were mainly detected in the cytoplasm. As expected, they also reveal a strong reduction in the number of interactions in both cell types after E2 treatment, (Fig. 1G). Finally, we detected a greater number of ER $\alpha /$ HSP70 interactions in untreated MRTFA- $\Delta$ N200 MCF7 cells, thereby confirming the perturbed monomer/dimer equilibrium in favor of the monomeric state in these cells.

In conclusion, the expression of the constitutive nuclear and active form of MRTFA in MCF7 cells down-regulates Apo-ER $\alpha$, its homodimerization and relocates the protein from the nucleus to the entire cell. The nuclear depletion of ER $\alpha$ homodimers was only very partially restored in the presence of E2.

\subsection{Apo-ERa binding to ERE sequences is strongly reduced after nuclear accumulation of MRTFA} in the luminal ER a positive breast cancer MCF7 cell line

Changes in Apo-ER $\alpha$ dynamic in MCF7 cells expressing the MRTFA- $\Delta$ N200 mutant should impact significantly the DNA binding capacity of ER $\alpha$, especially since le main ERBSs, the ERE motif, is bound only by an ER $\alpha$ dimer. We have previously established ER $\alpha$ transcriptome and cistrome in these cells and have shown that nuclear accumulation of MRTFA almost entirely abolished gene regulation by estrogen and reduced the number of ERBSs identified in control MCF7 cells in the absence or presence of E2 by 60-70\% (Jehanno et al., 2020). In light of the new data, we reanalyzed Apo-ER $\alpha$ cistrome in more detail. Thus, in addition to the loss of ERBSs, we also found that the ERBSs specifically identified in MCF7 expressing the mutant form of MRTFA shared little overlap with ER $\alpha$ cistromes determined in control cells (Fig. 2A). Particularly, only 31/454 genomic sites bound by ER $\alpha$ in the absence of E2 in MRTFA- $\Delta$ N200 expressing MCF7 cells were common with ER $\alpha$ cistromes determined in any of the other conditions (Fig. 2A). This led us to assess if Apo-ER $\alpha$ binding in these cells had any specific property. First, DNA binding motif analyses were carried out to investigate the possibility that ER $\alpha$ may bind to DNA with specific partners within these genomic regions. Strikingly, as shown in Fig. 2B, the types of motifs identified in MRTFA- $\triangle$ N200 MCF7 cells was extremely limited as compared to other conditions. This reflects the limited number of sites identified in these cells under untreated conditions. These results also showed a clear under-representation of the ERE motifs in the genomic regions bound by Apo-ER $\alpha$ in MRTFA- $\triangle$ N200 MCF7 cells (Fig. 2B). As illustrated in the bar chart in Fig. 2C, such a loss of enrichment was also observed on sequences known to indirectly recruit ER $\alpha$ through protein-protein interactions (AP and SP1), although the effect is not as drastic as in the case of ERE. Finally, when measuring the mean enrichment in ER $\alpha$ on all four cistromes (as evaluated from the ChIP-Seq signals), we determined that the genome-wide DNA binding affinity of Apo-ER $\alpha$ in MRTFA- $\triangle$ N200 MCF7 cells was significantly lower than in control cells, while no difference was observed in the presence of E2 (Fig. 2D). 
Taken together, these observations strengthen the hypothesis of a change in Apo-ER $\alpha$ monomer/dimer ratio towards the monomeric state in MCF7 cells expressing the MRTFA- $\triangle$ N200 mutant. They also led us to hypothesize that the nuclear accumulation of MRTFA in MCF7 might strongly influence which motifs and which protein-interactors ER $\alpha$ binds to exert its function.

\subsection{ER $\alpha$ interaction with P160 family coactivators is partly impacted by MRTFA-1 1 N200 expression in MCF7 cells}

To further explore ER $\alpha$ functional changes, we studied the expression, localization and ER $\alpha$ interaction of SRC1 and SRC3/AIB1, two steroid receptor coactivator P160 family members (Arnal et al., 2017; McKenna and O'Malley, 2002), in MRTFA- $\Delta$ N200 versus control cells. The amounts of SRC1 mRNA and protein levels were comparable between control and MRTFA- $\triangle$ N200 MCF7 cells, whereas SRC3 was two-fold induced in cells expressing nuclear MRTFA (data not shown, Fig. 3A). However, the cellular location of the coactivators exhibited major changes in the cell types. Indeed, as $\mathrm{ER} \alpha, \mathrm{SRC} 1$ and $\mathrm{SRC} 3$ were relocated from a main nuclear localization in control MCF7 cells to the whole volume of MRTFA-1 $\Delta$ N200 MCF7 cells (Fig. 3A). When measured by PLA, the interaction between ER $\alpha$ and the coactivators was detected in both the nuclear and cytoplasmic compartment of the cells (Fig. 3B). Interestingly, the expression of MRTFA- $\Delta$ N200 enhances the cytoplasmic localization of the interactions between ER $\alpha$ and SRC proteins, thus following the relocation of the corresponding proteins (Fig. 3B). This resulted in a decrease in the number of dots in the nucleus of untreated MRTFA- $\triangle$ N200 MCF7 cells. In contrast to control cells, E2 treatment strongly and uniformly enhanced ER $\alpha /$ SRC interactions in the entire MRTFA- $\Delta$ N200 MCF7 cells. Treatment of both cell types with the antagonist ICI 182,780 (ICI) abolished ER $\alpha / \mathrm{SRC}$ interactions as expected (see Supplementary Fig. S3A). Changes in the dynamic of ER $\alpha / \mathrm{SRC}$ interactions in MRTFA- $1 \Delta$ N200 MCF7 cells were specific to MRTFA- $\Delta$ N200 expression since MRTFA-1 $\Delta$ N200 MCF7 cells behave as control MCF7 cells in the absence of tetracycline treatment (see Supplementary Fig. S4A). On the other hand, jasplakinolide treatment exhibits no major effect on ER $\alpha / \mathrm{SRC}$ interactions in normal MCF7 and T47D cells, suggesting that the nuclear translocation of MRTFA alone is not sufficient to explain the effect of MRTFA-1 $\triangle \mathrm{N} 200$ on $\mathrm{ER} \alpha / \mathrm{SRC}$ interactions. It can be noted that the dynamic of ER $\alpha / \mathrm{SRC} 1$ interactions in T47D was similar to that observed in tetracycline-treated MRTFA- $\triangle$ N200 MCF7 cells.

\subsection{MRTFA nuclear translocation suppresses ER interaction with corepressors}

$\mathrm{ER} \alpha$ is also able to recruit corepressors, such as SMRT and NCOR1, to transcriptionally repress its target genes (Keeton and Brown, 2005; Lavinsky et al., 1998). We therefore monitored corepressor expression, localization and interaction with ER $\alpha$ following the nuclear accumulation of MRTFA in MCF7 cells. Immunofluorescence experiments showed mostly a nuclear staining for both corepressors; the signal was slightly stronger in MRTFA- $\triangle$ N200 MCF7 cells than in controls (Fig. 4A). The interaction between ER $\alpha$ and the corepressors, as determined by PLA, was observed in both the nuclear and cytoplasmic compartment of the MCF7 cells, often with a nuclear predominance. As expected, E2 treatment, as well as ICI treatment, abolished much of this interaction. (Fig. 4B and Supplementary Fig. S3). We also treated control MCF7 cells with 4hydrotamoxifen (OHT) because of its ability to promote the recruitment of corepressors by ER $\alpha$ in a tissue-specific manner (Shang and Brown, 2002). Results clearly show that OHT partly retained the interaction (Supplementary Fig. S3). Interestingly, the nuclear translocation of MRTFA$\triangle \mathrm{N} 200$ strongly inhibited ER $\alpha /$ corepressor interactions under all conditions (Fig. 4B and 
Supplementary Fig. S3B and S4B). The effect was also reproduced after jasplakinolide-induced nuclear translocation of the endogenous MRTFA, although the effect was less pronounced in T47D than MCF7 cells (Supplementary Fig. S1F). In conclusion, altogether, these results indicate that MRTFA's nuclear accumulation in luminal breast cancer cells may interfere with the repressive function of ER $\alpha$ on certain target genes by reducing ER $\alpha$ 's ability to interact with corepressors.

\subsection{MRTFA nuclear accumulation in MCF7 cells favors ERa interaction with several kinases in estrogen signaling pathways}

In addition to its transcriptional function, $\mathrm{ER} \alpha$ is also known to modulate non-genomic membrane signaling pathways through a protein pool located at the cytoplasm and/or plasma membrane (Arnal et al., 2017; Edwards, 2005b). Indeed, ER $\alpha$ interacts with several kinases such as c-src and PI3K, thereby regulating downstream MAPK and AKT signaling pathways. These data, together with the observed spread of ER $\alpha$ to the whole cell and the concomitant activation of MAPK signaling pathway after MRTFA nuclear translocation in MCF7 cells (Fig. 1A and Supplementary Fig. S1B), led us to assay ER $\alpha$ binding to with several potential interacting kinases. For that purpose, ER $\alpha / \mathrm{c}$-src and ER $\alpha / \mathrm{PI} 3 \mathrm{~K}$ interactions were investigated by PLA in both control and MRTFA- $\triangle$ N200 MCF7 cells (Fig. 5A). We clearly observed an interaction between ER $\alpha$ and the two kinases c-src and PI3K in control MCF7 cells, in line to similar observation in a series of 175 breast tumors by Poulard et al. (Poulard et al., 2012). The interactions were significantly up-regulated by E2. Of interest, the ER $\alpha /$ kinase complexes remarkably increased in MRTFA- $\triangle$ N200 MCF7 cells, which exhibit an ER $\alpha$ relocalization from the nucleus to the entire cell volume. In opposite to control MCF7 cells, the ER $\alpha /$ kinase complexes in MRTFA- $\Delta$ N200 MCF7 cells were slightly down regulated by E2 and up-regulated by ICI (Fig. 5B and Supplementary Fig. S3). These effects were observed only after induction of MRTFA- $\Delta$ N200 expression by tetracycline treatment (Supplementary Fig. S3C and S4C). Corroborating the data obtained from MRTFA- $\triangle$ N200 MCF7 cells, jasplakinolide treatment of normal MCF7 yielded similar results (Supplementary Fig. S1F). No major variations were observed in T47D cells.

To assess if the increase of ER $\mathrm{E} /$ kinase complexes has functional consequences, we next examined by Western blot the phosphorylation status of ERK and AKT in both control and MRTFA- $\triangle$ N200 MCF7 cell types transfected with either control or ER $\alpha$ siRNAs (Fig. 5, C and D). As expected, the expression of the MRTFA- $\triangle \mathrm{N} 200$ drastically increased ERK and AKT phosphorylation. MRTFA- $\Delta$ N200-induced phosphorylation of ERK and AKT was largely ER $\alpha$ dependent. Indeed, transfection of ER $\alpha$ siRNAs reduces it by at least $50 \%$. However, it was independent of ligands (Fig. 5D).

In conclusion, our results show that the expression of the constitutively active MRTFA$\triangle \mathrm{N} 200$ in MCF7 favors ER $\alpha$ interaction with partners of the non-genomic membrane signaling pathways and enhances ERK and AKT phosphorylation. 


\section{Discussion}

MRTFA is a master regulator of the epithelial-mesenchymal transition (EMT) and the metastatic process. We demonstrate in the present study that MRTFA-induced EMT in ER $\alpha$ positive breast cancer cells initiates changes in the expression and the functional properties of ER $\alpha$ shifting ER $\alpha$ activities from genomic to non-genomic function.

A remarkable feature of the ERBSs detected in untreated MRTFA- $\triangle$ N200 MCF7 cells was the absence of ERE motifs while they were the first elements found in control MCF7, as expected, but also in MRTFA- $\triangle$ N200 MCF7 treated with E2. To elucidate the reasons for this phenomenon, we thoroughly investigated ER $\alpha$ DNA binding and protein-interaction dynamics. ER $\alpha$ expression was rapidly down regulated after the expression of the MRTFA- $\Delta$ N200 mutant, reaching a level, which was, however, comparable to the one observed in control MCF7 cells treated with E2. A similar result was obtained after MRTFA nuclear translocation by a jasplakinolide treatment. The decrease in ER $\alpha$ expression is likely the result from both a decrease in the level of ER $\alpha$ mRNA expression and a degradation of ER $\alpha$ protein (Kerdivel et al., 2014). It was concomitant with the protein's redistribution throughout the entire cell, thereby deeply impacting ER $\alpha$ concentration in the nuclear compartment. Mechanistically, ER $\alpha$ relocation could be mediated by its interaction with chaperone proteins such as HSP70. Mainly present in the cytoplasm of control MCF7 cells, HSP70 is indeed partly found in the nucleus of MRTFA- $\triangle$ N200 MCF7 cells which could allow a relocalzation of ER $\alpha$ in the cytoplasm following the HSP70/ER $\alpha$ interaction.

According to the single mass action law, changes in ER $\alpha$ concentration should affect all reaction equilibria involving $\mathrm{ER} \alpha$, and first of all the equilibrium between the monomeric and dimeric forms of ER $\alpha$ itself. ER $\alpha$ has been shown to partly exist as a dimer in the absence of its ligand, although bound ligand enhances interaction between both monomers and dimer formation (Padron et al., 2007; Tamrazi et al., 2002). Earlier Scatchard analyses demonstrated cooperativity of $\left[{ }^{3} \mathrm{H}\right]-\mathrm{E} 2$ binding to ER $\alpha$, which was dependent on the monomer/dimer equilibrium resulting from ER $\alpha$ 's concentration in the tissue extract (Notides et al., 1981). A decrease in ER $\alpha$ concentration shifts the ER $\alpha$ monomer/dimer equilibrium in favor of the monomer, which reduces the cooperativity in ligand binding. A reduced amount of ER $\alpha$ homodimers was probably the reason why no cooperativity in E2-binding was observed in whole cell extract from MRTFA- $\Delta$ N200 MCF7 cells. This hypothesis was supported by PLA experiments specifically quantifying ER $\alpha$ homodimers in parental and mutant MCF7 cell types. This technique was used for the first time to our knowledge to specifically quantify ER $\alpha$ homodimers, a recurring question difficult to solve. The presence of ER $\alpha$ homodimer was indeed drastically reduced in the nucleus of cells expressing the MRTFA- $\Delta$ N200 protein. Moreover, the estrogenic treatment restored a number of homodimer only comparable to the one detected in untreated control MCF7 cells. Finally, the evaluation of the number of ER $\alpha$ complexes with the chaperone protein HSP70 detectable by PLA directly provides evidence that ER $\alpha$ is preferentially found as monomers in untreated MRTFA- $\triangle$ N200 MCF7 cells. Obviously, the combination of a significant decrease in the expression level of ER $\alpha$ and the resulting shift of the homodimer/monomer equilibrium towards the monomeric state may directly account for the reduced number of ERBS motifs and the lacking EREs that are detected in MRTFA$\triangle \mathrm{N} 200 \mathrm{MCF} 7$ cells. Since ER $\alpha$ binds ERE motifs in its dimeric form, these observations might further explain this depletion ERE motifs in the ERBSs bound in untreated MRTFA- $\triangle$ N200 MCF7 cells, but also the increase of ERE-enriched ERBSs after estrogen-induced ER $\alpha$ dimerization in treated cells.

Importantly, any changes of the ER $\alpha$ monomer/dimer equilibrium is expected to impact ER $\alpha$ interaction with co-regulators which are the genomic and non-genomic partners. Beside its ability to regulate gene expression by binding directly to DNA at EREs, ER $\alpha$ is also known to engage DNA via a tethering mechanism through protein-protein interactions with other transcription factors, such as AP1, Sp1, CEBP $\beta$, NF-אB or RUNX1 bound to their DNA binding site (Stender et al., 2010). 
Some of these DNA motifs were enriched within ERBSs of both MCF7 cell lines, however at a lower level of enrichment among ERBSs of untreated MRTFA- $\triangle$ N200 MCF7 cells. To date, no studies have specifically addressed whether these protein-protein interactions involve monomeric or dimeric forms of ER $\alpha$. In contrast, dimer formation is thought to be essential for coactivator recruitment by ER $\alpha$ as suggested by Florescence resonance energy transfer (FRET)-based approaches or recent cryoelectron microscopy studies (Kofoed et al., 2010; Tamrazi et al., 2002; Yi et al., 2015). While the receptor interacting domain (RIDs) of the SRC/P160 family of coactivators has the highest affinity for the dimeric form of ER $\alpha$, FRET experiments indicated that high RIDs concentration associated with low ER $\alpha$ amounts might promote complex formation with ER $\alpha$ monomers (Kofoed et al., 2010). SRC/P160 family proteins are the primary coactivators recruited by DNA-bound ER $\alpha$, which in turn recruits multiple secondary coactivators, such as CPB or P300, to form a minimal receptor-coactivator complex that promotes chromatin remodeling through histone acetyltransferase activities ( $\mathrm{Yi}$ et al., 2015). Consequently, we performed PLA experiments to monitor the interaction of P160 family proteins with ER $\alpha$ in MCF7 cells expressing or not MRTFA- $\triangle$ N200. Our data show differences between both MCF7 cell types. In particular, P160 coactivator/ER $\alpha$ interaction was not regulated by E2 in control MCF7 cells, whereas it was E2dependent in MRTFA- $\triangle$ N200 MCF7 cells. The unexpected ligand-independent formation of P160 coactivator/ER $\alpha$ complex in control MCF7 cells was abolished by an ICI treatment, confirming the specificity of the interaction. FRET- or BIAcore-based studies have described interactions between $\mathrm{ER} \alpha$ and SRC/P160 coactivators in the absence of ligand, whereby E2 increases their frequency and stability (Cheskis et al., 2003; Kofoed et al., 2010). Thus, the presence of large amounts of ER $\alpha$ homodimers in untreated control MCF7 cells might partially compensate in the recruitment of SRC/P160 family members by ER $\alpha$. In addition, specific phosphorylation of ER $\alpha$ by growth factor signaling pathways in the absence of ligand can also strengthen P160 coactivator/ER $\alpha$ interactions (Arnal et al., 2017). In contrast, the low proportion of ER $\alpha$ homodimers in untreated cells and the induction of dimerization in presence of E2 probably explain why the P160 coactivator/ER $\alpha$ interaction is E2-dependent in MRTFA- $\triangle$ N200 MCF7 cells. Nevertheless, the phenomenon is not reproduced after a jasplakinolide treatment. Lastly, the localization of the P160 coactivator/ER $\alpha$ interaction was also different in the MCF7 cell types. Indeed, the P160/ER $\alpha$ complexes were restricted to the nuclear compartment in control cells, but were redistributed to the whole cell in MRTFA- $\triangle$ N200 MCF7 cells, in agreement with the ER $\alpha$ relocation and a similar redistribution of SRC/P160 coactivators. Dynamic changes in the subcellular distribution of SRC/P160 coactivators were previously reported to be regulated by nuclear-cytoplasmic trafficking, phosphorylation or steroid receptor localization (Amazit et al., 2007, 2003). Although SRC/P160 protein recruitment by ER $\alpha$ appears to occur in the cytoplasm, the functional implications of these complexes remain to be defined.

In addition to its ability to recruit coactivators, ER $\alpha$ can also interact with corepressors to inactivate transcription (Keeton and Brown, 2005; Lavinsky et al., 1998). Although information on $\mathrm{ER} \alpha$ in particular remains limited (Heldring et al., 2007), dimer formation also appears to be essential for corepressor recruitment by members of the nuclear receptor family (Jeyakumar et al., 2008; Schoch et al., 2010; Xu et al., 2002). Our Results clearly show a drastic reduction in $\mathrm{ER} \alpha /$ corepressor interaction in MRTFA- $\Delta \mathrm{N} 200 \mathrm{MCF} 7$ cells or in jasplakinolide-treated MCF7 cells. This strong decrease in the interaction between ER $\alpha$ and SMRT/NCOR1 corepressors is probably due to a reduction in ER $\alpha$ expression level and the shift of its monomer/dimer ratio towards its monomeric state in these cells. However, our finding that OHT was unable to restore this interaction in MRTFA- $\Delta$ N200 MCF7 cells also suggests a significant change in the dynamics of recruitment of corepressors by ER $\alpha$ following MRTFA's nuclear accumulation. It is widely accepted that one the mechanisms responsible of the decreased therapeutic efficiency of tamoxifen in breast cancers is the loss of the ability of this molecule to induce corepressor recruitment by ER $\alpha$ (Katzenellenbogen and Katzenellenbogen, 2002; Shang and Brown, 2002; Smith et al., 1997). This 
mechanism might therefore partly explain our observation that the nuclear localization of MRTFA is associated with endocrine resistance in a cohort of breast cancer patients (Jehanno et al., 2020). It should be noted that, in addition to the expected recruitment of corepressors by ER $\alpha$ in the presence of OHT, an interaction between corepressors and Apo-ER $\alpha$ was also observed by PLA in control MCF7 cells. This contradicts the common view that, unlike most nuclear receptors, the estrogen receptor cannot repress transcription in the absence of SERMs. However, controversy also exists suggesting that corepressors are indeed involved in the repression of DNA-bound Apo-ER $\alpha$ (Dobrzycka et al., 2003). Direct corepressor recruitment by ER $\alpha$ is primarily mediated through amino acid residues from helices 3, 4, 5 and 11 in the C-terminal hormone-binding domain of the receptor (Xu et al., 2002), but is tightly regulated by the A domain located at the N-terminal end. Indeed, the latter either masks the hydrophobic surface recognized by the corepressors in the Cterminal hormone-binding domain (according to the final conformation adopted by the receptor) and thereby prevent corepressor/ ER $\alpha$ interactions (Métivier et al., 2002), or it causes the recruitment of TAB2 as a component of the NCOR corepressor complex (Zhu et al., 2006). TAB2 acts a sensor for inflammatory signals, which can prevent the NCOR/HDAC complex from exerting its function and thus mitigate the repression of estrogen receptor target genes (Zhu et al., 2006). These intricate regulatory interactions might lead to different functional outcomes according to the tissue and its pathophysiological state and might explain the controversy over the recruitment of the corepressors by Apo-ER $\alpha$.

Nuclear exclusion of ER $\alpha$ often promotes its non-nuclear signaling pathways. Hence, the receptor is targeted to the plasma membrane, particularly in the caveola rafts, where it physically interacts with multiple scaffold proteins and kinases (Arnal et al., 2017; Edwards, 2005b). Palmitoylation of ER $\alpha$ at cysteine 447 is a step required for caveolin-1 interaction and the resulting plasma membrane localization (Acconcia et al., 2005; Pedram et al., 2007). Of interest, palmitoylation occurs only on ER $\alpha$ monomers, whereby the reaction is enhanced by direct interaction of monomeric ER $\alpha$ with HSP27 (Razandi et al., 2010). Therefore, nuclear exclusion of ER $\alpha$ accompanied by strong interactions with the chaperone HSP70 and an ER $\alpha$ monomer/dimer equilibrium shifted toward monomers should render MRTFA- $\triangle$ N200 MCF7 cells highly permissive to non-genomic signaling by ER $\alpha$. Using PLA to monitor ER $\alpha / \mathrm{c}-\mathrm{src}$ and ER $\alpha / \mathrm{PI} 3 \mathrm{~K}$ interactions in breast cancers, we demonstrate that the expression of the constitutively active form of MRTFA indeed greatly enhances ER $\alpha$ complexes with non-genomic signaling partners. Likewise, ER $\alpha / \mathrm{c}-\mathrm{src}$ interactions were clearly induced in jasplakinolide-treated MCF7 cells. The regulation was mostly ligand-independent. A strong ER $\alpha$ /kinase complex formation indeed occurred in the absence of E2. Downstream effectors such as ERK and AKT, were also found to be highly phosphorylated in an E2-independent manner. Finally, both ER $\alpha / \mathrm{c}$-src interaction and effector phosphorylation were not antagonized by ICI in MRTFA- $\triangle$ N200 MCF7 cells. The fact that ICI maintains or even promotes $\mathrm{ER} \alpha / \mathrm{c}$-src interactions despite of its capacity for full ER $\alpha$ antagonism, remains to be elucidated. Its inhibitory action on ER $\alpha$ expression level associated with a change in ER $\alpha$ conformation could favor the shift of ER $\alpha$ monomer/dimer ratio towards the monomeric state and thus promote ER $\alpha /$ kinase interactions. Consequently, enhancement of MAPK and AKT signaling pathways in MCF7 cells expressing nuclear MRTFA protein seems to be based in part on ER $\alpha$-dependent mechanisms, whereby the interplay between ER $\alpha$ and agonist/antagonist ligands is modified.

In view of the functional consequences of nuclear translocation of MRTFA in luminal breast cancer cells, our results thus strengthen the hypothesis that the non-genomic signaling function of $\mathrm{ER} \alpha$ is associated with resistance to endocrine therapy and poor prognosis in human breast cancers (Poulard et al., 2012). Interestingly, Madak-Erdogan et al. have previously showed, using the PLA approach, that among its non-genomic functions, ER $\alpha$ interacts with the scaffolding protein RAPTOR, a major component of the mTOR signaling pathway known to be deregulated in the resistance to endocrine therapy (Madak-Erdogan et al., 2016). Their studies have also stressed the importance of a dynamic interplay between ER $\alpha$ signaling and actin reorganization through the 
ERK5/cofilin network in phenotypes of breast cancer aggressiveness (Madak-Erdogan et al., 2014).

The study was essentially developed on MCF7, the cell line model commonly used to study luminal breast cancers. The use of another luminal breast cancer cell line, the T47D, allows us to confirm only part of the results. Notably, the increase in the interaction between ER $\alpha$ and c-src after a jasplakinolide-induced MRTFA translocation was not observed in T47D. We believe that these differences are probably due to the fact that T47D are less differentiated than MCF7 cells, more closely resembling to a luminal B-type phenotype. Indeed, they express fewer estrogen receptors and the regulation of the estrogen-target genes is of lower amplitude(Jehanno et al., 2020). Finally, they have many actin stress fibers which MCF7 do not.

Our study highlights major functional changes in ER $\alpha$ 's activity during MRTFA-induced EMT of breast cancer cells. Relocation of ER $\alpha$ protein from the nucleus to the entire cell and a shift towards its monomer state induce a decline in genomic activity of ER $\alpha$ and favor its non-genomic signaling activity. We conclude that EMT in breast cancer likely involves dramatically altered ER $\alpha$ activity in tumor tissues and that MRTFA is an important biomarker and actor for the progression of malign mammary tumors to the metastatic stage. 


\section{Funding}

This work was supported by the University of Rennes 1, Inserm, CNRS, and the Ligue Contre le Cancer.

\section{Acknowledgements}

We thank the IGBMC Micrroarray and Sequencing platform at Illkrich.

\section{Author contributions}

G.F. designed the project. C.J., F.P. P.G. N.B. and G.F. conducted the experiments. C.F., JF.A., D.M., F.P. and R.M. contributed to data analysis. C.J., M. P., R.M. and G.F. wrote the manuscript with input from all authors.

\section{Declaration of competing interest}

The authors have nothing to disclosure.

\section{Supplementary data}

Supplementary Fig. 1: Effects of jasplakinolide on ER $\alpha$ and MRTFA subcellular localization and on the interaction of ER $\alpha$ with SRC1, SMRT and src in MCF7 and T47D cells.

Supplementary Fig. 2: In situ detection of endogenous ER $\alpha$ dimer complex in MCF7 cells by PLA assays.

Supplementary Fig. 3: Effects of ER $\alpha$ antagonists on the interaction of ER $\alpha$ with SRC1, SMRT and src in control and MRTFA- $\triangle$ N200 MCF7 cells.

Supplementary Fig. 4. Interaction of ER $\alpha$ with SRC1, SMRT and src in MRTFA- $\triangle$ N200 MCF7 cells in the absence of induction of MRTFA- $\Delta$ N200 expression. 


\section{References}

Acconcia, F., Ascenzi, P., Bocedi, A., Spisni, E., Tomasi, V., Trentalance, A., Visca, P., Marino, M., 2005. Palmitoylation-dependent estrogen receptor alpha membrane localization: regulation by 17beta-estradiol. Mol. Biol. Cell 16, 231-237. https://doi.org/10.1091/mbc.E04-07-0547

Amazit, L., Alj, Y., Tyagi, R.K., Chauchereau, A., Loosfelt, H., Pichon, C., Pantel, J., FoulonGuinchard, E., Leclerc, P., Milgrom, E., Guiochon-Mantel, A., 2003. Subcellular localization and mechanisms of nucleocytoplasmic trafficking of steroid receptor coactivator-1. J. Biol. Chem. 278, 32195-32203. https://doi.org/10.1074/jbc.M300730200

Amazit, L., Pasini, L., Szafran, A.T., Berno, V., Wu, R.-C., Mielke, M., Jones, E.D., Mancini, M.G., Hinojos, C.A., O’Malley, B.W., Mancini, M.A., 2007. Regulation of SRC-3 intercompartmental dynamics by estrogen receptor and phosphorylation. Mol. Cell. Biol. 27, 6913-6932. https://doi.org/10.1128/MCB.01695-06

Arnal, J.-F., Lenfant, F., Metivier, R., Flouriot, G., Henrion, D., Adlanmerini, M., Fontaine, C., Gourdy, P., Chambon, P., Katzenellenbogen, B., Katzenellenbogen, J., 2017. Membrane and Nuclear Estrogen Receptor Alpha Actions: From Tissue Specificity to Medical Implications. Physiol. Rev. 97, 1045-1087. https://doi.org/10.1152/physrev.00024.2016

Beato, M., 1989. Gene regulation by steroid hormones. Cell 56, 335-344.

Carroll, J.S., Meyer, C.A., Song, J., Li, W., Geistlinger, T.R., Eeckhoute, J., Brodsky, A.S., Keeton, E.K., Fertuck, K.C., Hall, G.F., Wang, Q., Bekiranov, S., Sementchenko, V., Fox, E.A., Silver, P.A., Gingeras, T.R., Liu, X.S., Brown, M., 2006. Genome-wide analysis of estrogen receptor binding sites. Nat. Genet. 38, 1289-1297. https://doi.org/10.1038/ng1901

Cheskis, B.J., McKenna, N.J., Wong, C.-W., Wong, J., Komm, B., Lyttle, C.R., O’Malley, B.W., 2003. Hierarchical affinities and a bipartite interaction model for estrogen receptor isoforms and full-length steroid receptor coactivator (SRC/p160) family members. J. Biol. Chem. 278, 1327113277. https://doi.org/10.1074/jbc.M211031200

Clarke, R., Tyson, J.J., Dixon, J.M., 2015. Endocrine resistance in breast cancer--An overview and update. Mol. Cell. Endocrinol. 418 Pt 3, 220-234. https://doi.org/10.1016/j.mce.2015.09.035

Couse, J.F., Korach, K.S., 1999. Estrogen receptor null mice: what have we learned and where will they lead us? Endocr. Rev. 20, 358-417. https://doi.org/10.1210/edrv.20.3.0370

Dahlman-Wright, K., Cavailles, V., Fuqua, S.A., Jordan, V.C., Katzenellenbogen, J.A., Korach, K.S., Maggi, A., Muramatsu, M., Parker, M.G., Gustafsson, J.-A., 2006. International Union of Pharmacology. LXIV. Estrogen receptors. Pharmacol. Rev. 58, 773-781. https://doi.org/10.1124/pr.58.4.8

Dhamad, A.E., Zhou, Z., Zhou, J., Du, Y., 2016. Systematic Proteomic Identification of the Heat Shock Proteins (Hsp) that Interact with Estrogen Receptor Alpha (ER $\alpha)$ and Biochemical Characterization of the ER $\alpha-H s p 70$ Interaction. PloS One 11, e0160312. https://doi.org/10.1371/journal.pone.0160312

Dobrzycka, K.M., Townson, S.M., Jiang, S., Oesterreich, S., 2003. Estrogen receptor corepressors - a role in human breast cancer? Endocr. Relat. Cancer 10, 517-536. https://doi.org/10.1677/erc.0.0100517

Edwards, D.P., 2005a. Regulation of signal transduction pathways by estrogen and progesterone. Annu. Rev. Physiol. 67, 335-376. https://doi.org/10.1146/annurev.physiol.67.040403.120151

Edwards, D.P., 2005b. Regulation of signal transduction pathways by estrogen and progesterone. Annu. Rev. Physiol. 67, 335-376. https://doi.org/10.1146/annurev.physiol.67.040403.120151

Evans, R.M., 1988. The steroid and thyroid hormone receptor superfamily. Science 240, 889-895.

Flouriot, G., Huet, G., Demay, F., Pakdel, F., Boujrad, N., Michel, D., 2014. The actin/MKL1 signalling pathway influences cell growth and gene expression through large-scale chromatin reorganization and histone post-translational modifications. Biochem. J. 461, 257-268. https://doi.org/10.1042/BJ20131240 
Gurbuz, I., Ferralli, J., Roloff, T., Chiquet-Ehrismann, R., Asparuhova, M.B., 2014. SAP domaindependent Mkll signaling stimulates proliferation and cell migration by induction of a distinct gene set indicative of poor prognosis in breast cancer patients. Mol. Cancer 13, 22. https://doi.org/10.1186/1476-4598-13-22

Heldring, N., Pawson, T., McDonnell, D., Treuter, E., Gustafsson, J.-A., Pike, A.C.W., 2007. Structural insights into corepressor recognition by antagonist-bound estrogen receptors. J. Biol. Chem. 282, 10449-10455. https://doi.org/10.1074/jbc.M611424200

Jehanno, C., Fernandez-Calero, T., Habauzit, D., Avner, S., Percevault, F., Jullion, E., Le Goff, P., Coissieux, M.M., Muenst, S., Marin, M., Michel, D., Métivier, R., Flouriot, G., 2020. Nuclear accumulation of MKL1 in luminal breast cancer cells impairs genomic activity of ER $\alpha$ and is associated with endocrine resistance. Biochim. Biophys. Acta Gene Regul. Mech. 194507. https://doi.org/10.1016/j.bbagrm.2020.194507

Jeyakumar, M., Webb, P., Baxter, J.D., Scanlan, T.S., Katzenellenbogen, J.A., 2008. Quantification of ligand-regulated nuclear receptor corepressor and coactivator binding, key interactions determining ligand potency and efficacy for the thyroid hormone receptor. Biochemistry 47 , 7465-7476. https://doi.org/10.1021/bi800393u

Jordan, V.C., O’Malley, B.W., 2007. Selective estrogen-receptor modulators and antihormonal resistance in breast cancer. J. Clin. Oncol. Off. J. Am. Soc. Clin. Oncol. 25, 5815-5824. https://doi.org/10.1200/JCO.2007.11.3886

Katzenellenbogen, B.S., Katzenellenbogen, J.A., 2002. Biomedicine. Defining the "S" in SERMs. Science 295, 2380-2381. https://doi.org/10.1126/science.1070442

Keeton, E.K., Brown, M., 2005. Cell cycle progression stimulated by tamoxifen-bound estrogen receptor-alpha and promoter-specific effects in breast cancer cells deficient in N-CoR and SMRT. Mol. Endocrinol. Baltim. Md 19, 1543-1554. https://doi.org/10.1210/me.2004-0395

Kerdivel, G., Boudot, A., Habauzit, D., Percevault, F., Demay, F., Pakdel, F., Flouriot, G., 2014. Activation of the MKL1/actin signaling pathway induces hormonal escape in estrogenresponsive breast cancer cell lines. Mol. Cell. Endocrinol. 390, 34-44. https://doi.org/10.1016/j.mce.2014.03.009

Kofoed, E.M., Guerbadot, M., Schaufele, F., 2010. Structure, affinity, and availability of estrogen receptor complexes in the cellular environment. J. Biol. Chem. 285, 2428-2437. https://doi.org/10.1074/jbc.M109.045203

Kuukasjärvi, T., Kononen, J., Helin, H., Holli, K., Isola, J., 1996. Loss of estrogen receptor in recurrent breast cancer is associated with poor response to endocrine therapy. J. Clin. Oncol. Off. J. Am. Soc. Clin. Oncol. 14, 2584-2589. https://doi.org/10.1200/JCO.1996.14.9.2584

Lavinsky, R.M., Jepsen, K., Heinzel, T., Torchia, J., Mullen, T.M., Schiff, R., Del-Rio, A.L., Ricote, M., Ngo, S., Gemsch, J., Hilsenbeck, S.G., Osborne, C.K., Glass, C.K., Rosenfeld, M.G., Rose, D.W., 1998. Diverse signaling pathways modulate nuclear receptor recruitment of N-CoR and SMRT complexes. Proc. Natl. Acad. Sci. U. S. A. 95, 2920-2925. https://doi.org/10.1073/pnas.95.6.2920

Lindström, S., Thompson, D.J., Paterson, A.D., Li, J., Gierach, G.L., Scott, C., Stone, J., Douglas, J.A., dos-Santos-Silva, I., Fernandez-Navarro, P., Verghase, J., Smith, P., Brown, J., Luben, R., Wareham, N.J., Loos, R.J.F., Heit, J.A., Pankratz, V.S., Norman, A., Goode, E.L., Cunningham, J.M., deAndrade, M., Vierkant, R.A., Czene, K., Fasching, P.A., Baglietto, L., Southey, M.C., Giles, G.G., Shah, K.P., Chan, H.-P., Helvie, M.A., Beck, A.H., Knoblauch, N.W., Hazra, A., Hunter, D.J., Kraft, P., Pollan, M., Figueroa, J.D., Couch, F.J., Hopper, J.L., Hall, P., Easton, D.F., Boyd, N.F., Vachon, C.M., Tamimi, R.M., 2014. Genome-wide association study identifies multiple loci associated with both mammographic density and breast cancer risk. Nat. Commun. 5, 5303. https://doi.org/10.1038/ncomms6303

Madak-Erdogan, Z., Kim, S.H., Gong, P., Zhao, Y.C., Zhang, H., Chambliss, K.L., Carlson, K.E., Mayne, C.G., Shaul, P.W., Korach, K.S., Katzenellenbogen, J.A., Katzenellenbogen, B.S., 2016. 
Design of pathway preferential estrogens that provide beneficial metabolic and vascular effects without stimulating reproductive tissues. Sci. Signal. 9, ra53. https://doi.org/10.1126/scisignal.aad8170

Madak-Erdogan, Z., Ventrella, R., Petry, L., Katzenellenbogen, B.S., 2014. Novel roles for ERK5 and cofilin as critical mediators linking ER $\alpha$-driven transcription, actin reorganization, and invasiveness in breast cancer. Mol. Cancer Res. MCR 12, 714-727. https://doi.org/10.1158/1541-7786.MCR-13-0588

McKenna, N.J., O’Malley, B.W., 2002. Combinatorial control of gene expression by nuclear receptors and coregulators. Cell 108, 465-474.

Medjkane, S., Perez-Sanchez, C., Gaggioli, C., Sahai, E., Treisman, R., 2009. Myocardin-related transcription factors and SRF are required for cytoskeletal dynamics and experimental metastasis. Nat. Cell Biol. 11, 257-268. https://doi.org/10.1038/ncb1833

Métivier, R., Penot, G., Hübner, M.R., Reid, G., Brand, H., Kos, M., Gannon, F., 2003. Estrogen receptor-alpha directs ordered, cyclical, and combinatorial recruitment of cofactors on a natural target promoter. Cell 115, 751-763.

Métivier, R., Stark, A., Flouriot, G., Hübner, M.R., Brand, H., Penot, G., Manu, D., Denger, S., Reid, G., Kos, M., Russell, R.B., Kah, O., Pakdel, F., Gannon, F., 2002. A dynamic structural model for estrogen receptor-alpha activation by ligands, emphasizing the role of interactions between distant A and E domains. Mol. Cell 10, 1019-1032. https://doi.org/10.1016/s10972765(02)00746-3

Miralles, F., Posern, G., Zaromytidou, A.-I., Treisman, R., 2003. Actin dynamics control SRF activity by regulation of its coactivator MAL. Cell 113, 329-342.

Notides, A.C., Lerner, N., Hamilton, D.E., 1981. Positive cooperativity of the estrogen receptor. Proc. Natl. Acad. Sci. U. S. A. 78, 4926-4930.

Osborne, C.K., 1998. Steroid hormone receptors in breast cancer management. Breast Cancer Res. Treat. 51, 227-238.

Padron, A., Li, L., Kofoed, E.M., Schaufele, F., 2007. Ligand-selective interdomain conformations of estrogen receptor-alpha. Mol. Endocrinol. Baltim. Md 21, 49-61. https://doi.org/10.1210/me.2006-0075

Pedram, A., Razandi, M., Sainson, R.C.A., Kim, J.K., Hughes, C.C., Levin, E.R., 2007. A conserved mechanism for steroid receptor translocation to the plasma membrane. J. Biol. Chem. 282, 22278-22288. https://doi.org/10.1074/jbc.M611877200

Penot, G., Le Péron, C., Mérot, Y., Grimaud-Fanouillère, E., Ferrière, F., Boujrad, N., Kah, O., Saligaut, C., Ducouret, B., Métivier, R., Flouriot, G., 2005. The human estrogen receptor-alpha isoform hERalpha46 antagonizes the proliferative influence of hERalpha66 in MCF7 breast cancer cells. Endocrinology 146, 5474-5484. https://doi.org/10.1210/en.2005-0866

Perou, C.M., Sørlie, T., Eisen, M.B., van de Rijn, M., Jeffrey, S.S., Rees, C.A., Pollack, J.R., Ross, D.T., Johnsen, H., Akslen, L.A., Fluge, O., Pergamenschikov, A., Williams, C., Zhu, S.X., Lønning, P.E., Børresen-Dale, A.L., Brown, P.O., Botstein, D., 2000. Molecular portraits of human breast tumours. Nature 406, 747-752. https://doi.org/10.1038/35021093

Pipes, G.C.T., Creemers, E.E., Olson, E.N., 2006. The myocardin family of transcriptional coactivators: versatile regulators of cell growth, migration, and myogenesis. Genes Dev. 20, 1545-1556. https://doi.org/10.1101/gad.1428006

Platet, N., Cathiard, A.M., Gleizes, M., Garcia, M., 2004. Estrogens and their receptors in breast cancer progression: a dual role in cancer proliferation and invasion. Crit. Rev. Oncol. Hematol. 51, 55-67. https://doi.org/10.1016/j.critrevonc.2004.02.001

Poulard, C., Treilleux, I., Lavergne, E., Bouchekioua-Bouzaghou, K., Goddard-Léon, S., Chabaud, S., Trédan, O., Corbo, L., Le Romancer, M., 2012. Activation of rapid oestrogen signalling in aggressive human breast cancers. EMBO Mol. Med. 4, 1200-1213. https://doi.org/10.1002/emmm.201201615 
Pratt, W.B., Toft, D.O., 1997. Steroid receptor interactions with heat shock protein and immunophilin chaperones. Endocr. Rev. 18, 306-360. https://doi.org/10.1210/edrv.18.3.0303

Purrington, K.S., Slager, S., Eccles, D., Yannoukakos, D., Fasching, P.A., Miron, P., Carpenter, J., Chang-Claude, J., Martin, N.G., Montgomery, G.W., Kristensen, V., Anton-Culver, H., Goodfellow, P., Tapper, W.J., Rafiq, S., Gerty, S.M., Durcan, L., Konstantopoulou, I., Fostira, F., Vratimos, A., Apostolou, P., Konstanta, I., Kotoula, V., Lakis, S., Dimopoulos, M.A., Skarlos, D., Pectasides, D., Fountzilas, G., Beckmann, M.W., Hein, A., Ruebner, M., Ekici, A.B., Hartmann, A., Schulz-Wendtland, R., Renner, S.P., Janni, W., Rack, B., Scholz, C., Neugebauer, J., Andergassen, U., Lux, M.P., Haeberle, L., Clarke, C., Pathmanathan, N., Rudolph, A., Flesch-Janys, D., Nickels, S., Olson, J.E., Ingle, J.N., Olswold, C., Slettedahl, S., Eckel-Passow, J.E., Anderson, S.K., Visscher, D.W., Cafourek, V.L., Sicotte, H., Prodduturi, N., Weiderpass, E., Bernstein, L., Ziogas, A., Ivanovich, J., Giles, G.G., Baglietto, L., Southey, M., Kosma, V.-M., Fischer, H.-P., GENICA Network, Reed, M.W.R., Cross, S.S., DemingHalverson, S., Shrubsole, M., Cai, Q., Shu, X.-O., Daly, M., Weaver, J., Ross, E., Klemp, J., Sharma, P., Torres, D., Rüdiger, T., Wölfing, H., Ulmer, H.-U., Försti, A., Khoury, T., Kumar, S., Pilarski, R., Shapiro, C.L., Greco, D., Heikkilä, P., Aittomäki, K., Blomqvist, C., Irwanto, A., Liu, J., Pankratz, V.S., Wang, X., Severi, G., Mannermaa, A., Easton, D., Hall, P., Brauch, H., Cox, A., Zheng, W., Godwin, A.K., Hamann, U., Ambrosone, C., Toland, A.E., Nevanlinna, H., Vachon, C.M., Couch, F.J., 2014. Genome-wide association study identifies 25 known breast cancer susceptibility loci as risk factors for triple-negative breast cancer. Carcinogenesis 35, 1012-1019. https://doi.org/10.1093/carcin/bgt404

Razandi, M., Pedram, A., Levin, E.R., 2010. Heat shock protein 27 is required for sex steroid receptor trafficking to and functioning at the plasma membrane. Mol. Cell. Biol. 30, 3249-3261. https://doi.org/10.1128/MCB.01354-09

Schoch, G.A., D’Arcy, B., Stihle, M., Burger, D., Bär, D., Benz, J., Thoma, R., Ruf, A., 2010. Molecular switch in the glucocorticoid receptor: active and passive antagonist conformations. J. Mol. Biol. 395, 568-577. https://doi.org/10.1016/j.jmb.2009.11.011

Shang, Y., Brown, M., 2002. Molecular determinants for the tissue specificity of SERMs. Science 295, 2465-2468. https://doi.org/10.1126/science.1068537

Smith, C.L., Nawaz, Z., O'Malley, B.W., 1997. Coactivator and corepressor regulation of the agonist/antagonist activity of the mixed antiestrogen, 4-hydroxytamoxifen. Mol. Endocrinol. Baltim. Md 11, 657-666. https://doi.org/10.1210/mend.11.6.0009

Sørlie, T., Perou, C.M., Tibshirani, R., Aas, T., Geisler, S., Johnsen, H., Hastie, T., Eisen, M.B., van de Rijn, M., Jeffrey, S.S., Thorsen, T., Quist, H., Matese, J.C., Brown, P.O., Botstein, D., Lønning, P.E., Børresen-Dale, A.L., 2001. Gene expression patterns of breast carcinomas distinguish tumor subclasses with clinical implications. Proc. Natl. Acad. Sci. U. S. A. 98, 10869-10874. https://doi.org/10.1073/pnas.191367098

Stender, J.D., Kim, K., Charn, T.H., Komm, B., Chang, K.C.N., Kraus, W.L., Benner, C., Glass, C.K., Katzenellenbogen, B.S., 2010. Genome-wide analysis of estrogen receptor alpha DNA binding and tethering mechanisms identifies Runx1 as a novel tethering factor in receptormediated transcriptional activation. Mol. Cell. Biol. 30, 3943-3955. https://doi.org/10.1128/MCB.00118-10

Sun, Y., Boyd, K., Xu, W., Ma, J., Jackson, C.W., Fu, A., Shillingford, J.M., Robinson, G.W., Hennighausen, L., Hitzler, J.K., Ma, Z., Morris, S.W., 2006. Acute myeloid leukemia-associated Mkl1 (Mrtf-a) is a key regulator of mammary gland function. Mol. Cell. Biol. 26, 5809-5826. https://doi.org/10.1128/MCB.00024-06

Tamrazi, A., Carlson, K.E., Daniels, J.R., Hurth, K.M., Katzenellenbogen, J.A., 2002. Estrogen receptor dimerization: ligand binding regulates dimer affinity and dimer dissociation rate. Mol. Endocrinol. Baltim. Md 16, 2706-2719. https://doi.org/10.1210/me.2002-0250

Xu, H.E., Stanley, T.B., Montana, V.G., Lambert, M.H., Shearer, B.G., Cobb, J.E., McKee, D.D., 
Galardi, C.M., Plunket, K.D., Nolte, R.T., Parks, D.J., Moore, J.T., Kliewer, S.A., Willson, T.M., Stimmel, J.B., 2002. Structural basis for antagonist-mediated recruitment of nuclear corepressors by PPARalpha. Nature 415, 813-817. https://doi.org/10.1038/415813a

Yi, P., Wang, Z., Feng, Q., Pintilie, G.D., Foulds, C.E., Lanz, R.B., Ludtke, S.J., Schmid, M.F., Chiu, W., O’Malley, B.W., 2015. Structure of a biologically active estrogen receptor-coactivator complex on DNA. Mol. Cell 57, 1047-1058. https://doi.org/10.1016/j.molcel.2015.01.025

Zhu, P., Baek, S.H., Bourk, E.M., Ohgi, K.A., Garcia-Bassets, I., Sanjo, H., Akira, S., Kotol, P.F., Glass, C.K., Rosenfeld, M.G., Rose, D.W., 2006. Macrophage/cancer cell interactions mediate hormone resistance by a nuclear receptor derepression pathway. Cell 124, 615-629. https://doi.org/10.1016/j.cell.2005.12.032 


\section{Figure legends}

Fig. 1. Expression of MRTFA- $\Delta \mathrm{N} 200$ in MCF7 impacts ERa subcellular localization and its monomer/dimer equilibrium. (A), Induction kinetic of MRTFA- $\triangle$ N200 in MCF7 subclone cells. Control and MRTFA- $\triangle$ N200 MCF7 cells were harvested after 0,24 and 48h of tetracycline treatment $(1 \mu \mathrm{g} / \mathrm{mL})$. Total proteins from MCF7 subclones were immunoblotted for MRTFA, flag, ER $\alpha$, phospho-ERK (p-ERK), ERK and $\beta$ actin. MRTFA- $\Delta$ N200 was fused to flag epitope. (B) and (C), Shown are pictures of immunofluorescent detection of the subcellular localization of ER $\alpha$ and MRTFA in control MCF7 and MRTFA- $\triangle$ N200 MCF7 cells after 48h of tetracycline treatment. Scale bar $=10 \mu \mathrm{m}$. For MRTFA, the graph represents the percentage of cells with a MRTFA nuclear staining. For ER $\alpha$, the bar chart represents the fluorescence intensity as measured through densitometry quantification, expressed as a percentage of the intensity measured in control MCF7 cells. The respective proportion of ER $\alpha$ nuclear and cytoplasmic staining is indicated. Error bars represent SEM ( $\mathrm{n}=10$ to $15 ; \mathrm{P}<0.01$, student 's $t$-test). (D), Western blot analysis of ER $\alpha, \mathrm{HSP} 70$, ERK, $\alpha$ tubuline and lamin $C$ levels in nuclear and cytoplasmic fractions of control and MRTFA$\triangle \mathrm{N} 200 \mathrm{MCF} 7$ cells treated $48 \mathrm{~h}$ with tetracycline and stimulated or not with $10 \mathrm{nM}$ E2 during the last $24 \mathrm{~h}$. (E), Scatchard analysis of the specific $\left[{ }^{3} \mathrm{H}\right]$ estradiol binding was performed as described in the materials and methods on whole cell extracts prepared from control and MRTFA- $\Delta$ N200 MCF7 cells treated $48 \mathrm{~h}$ with tetracycline. The specific equilibrium binding and the Scatchard plot analysis are shown, with a $\mathrm{K}_{\mathrm{d}}$ of $0.4 \mathrm{nM}$ for both cell types. Values represent the average of 3 independent experiments. (F), ER $\alpha$ dimer complexes were detected by PLA in control and MRTFA- $\triangle$ N200 MCF7 cells treated $48 \mathrm{~h}$ with tetracycline and stimulated or not with $10 \mathrm{nM}$ E2 during $60 \mathrm{~min}$. PLA was performed using an ER $\alpha$ monoclonal antibody (sp1) directly conjugated to the PLA MINUS and PLUS oligonucleotides. The detected dimers are visible as red dots. Scale bar $=10 \mu \mathrm{m}$. Quantification of the number of dots/cell and dots/nucleus was performed using ImageJ software and was then expressed as a percentage of the number of dots/cell measured in untreated control MCF7 cells. The respective proportion of dimer/dots in the nucleus and in the cytoplasm is shown. Values represent the mean $+/$ - SEM. Columns with different superscripts differ significantly ( $\mathrm{n}=60 ; \mathrm{P}<0.05$, student 's $t$-test). (G), ER $\alpha /$ HSP70 interactions were detected by PLA in control and MRTFA- $\triangle$ N200 MCF7 cells treated $48 \mathrm{~h}$ with tetracycline and stimulated or not with $10 \mathrm{nM}$ E2 during $60 \mathrm{~min}$. The respective proportion of dots in the nucleus and in the cytoplasm is shown. Values represent the mean +/- SEM and are expressed as a percentage of the number of dots/cell measured in untreated control MCF7 cells. Columns with different superscripts differ significantly ( $\mathrm{n}=30 ; \mathrm{P}<0.05$, student 's $t$-test).

Fig. 2. Nuclear accumulation of MRTFA in MCF7 impairs Apo-ERa binding to ERE sequences. (A), Venn diagram illustrating the overlap of genomic regions bound by ER $\alpha$ in control MCF7 cells or MCF7 cells expressing the MRTFA- $\triangle$ N200 protein following a 50 min treatment with either E2 or ethanol (EtOH) as vehicle control, as previously determined (Jehanno et al., 2020). (B), Table showing the top 20 of transcription factor binding motifs identified by the CentDist algorithm within ERBSs from control MCF7 cells or MCF7 cells expressing the MRTFA$\triangle$ N200 mutant. (C), Histogram depicting the CentDist enrichment scores of ERE, AP(1/2/4) and SP1 motifs within the ER cistromes identified in the 4 conditions shown in control MCF7 cells or MRTFA- $\triangle$ N200 MCF7 cells treated with E2 or EtOH. (D), Mean enrichment of ER on its sites in the 4 depicted conditions, as calculated from the ChIP-seq signal measured within the central $50 \mathrm{bp}$ of each ERBS. Columns with different superscripts differ significantly $(P<0.05$, Anova, post analysis: Bonferroni).

Fig. 3. Expression of MRTFA- $\Delta \mathbf{N 2 0 0}$ protein in MCF7 cells impacts the dynamic interaction of ERa with coactivators from the P160 family. (A), The subcellular localization of SRC1 and 
SRC3 in control and MRTFA- $\triangle$ N200 MCF7 cells after 48h tetracycline treatment was determined using immunofluorescent detection. Representative pictures of these experiments are shown, and were used to measure the signal intensity by densitometry quantification. Mean values shown within the graph are expressed as a percentage of the intensity measured in control MCF7 cells. The respective proportion of nuclear and cytoplasmic staining of the P160 coactivators is indicated. Error bars represent SEM ( $\mathrm{n}=15$ to $20 ; \mathrm{P}<0.01$, student 's $t$-test). (B), ER $\alpha / \mathrm{P} 160$ coactivator complexes were detected by PLA in control and MRTFA- $\triangle \mathrm{N} 200$ MCF7 cells treated 48h with tetracycline and stimulated or not with $10 \mathrm{nM}$ E2 during 60 min. PLA was performed using ER $\alpha$, SRC1 and SRC3 specific antibodies. Representative pictures of these experiments are shown with dapi-stained nuclei. Quantification of the number of dots/cell and dots/nucleus was performed using ImageJ software and was then expressed as a percentage of the number of dots/cell measured in untreated control MCF7 cells. The respective proportion of complex/dots in the nucleus and in the cytoplasm is shown. Values represent the mean $+/$ - SEM. Columns with different superscripts differ significantly ( $\mathrm{n}=30$ to $40 ; \mathrm{P}<0.05$, student 's $t$-test).

Fig. 4. Expression of MRTFA- $\Delta$ N200 protein in MCF7 cells impacts the dynamic interaction of ERa with the corepressors SMRT and NCOR1. (A), The subcellular localization of SMRT and NCOR1 in control and MRTFA- $\triangle \mathrm{N} 200 \mathrm{MCF} 7$ cells after $48 \mathrm{~h}$ tetracycline treatment was determined using immunofluorescent detection. Representative pictures of these experiments are shown, and were used to measure the signal intensity by densitometry quantification. Mean values shown within the graph are expressed as a percentage of the intensity measured in control MCF7 cells. The respective proportion of nuclear and cytoplasmic staining of the corepressors is indicated. Error bars represent SEM ( $\mathrm{n}=15$ to 20; $\mathrm{P}<0.01$, student 's $t$-test). (B), ER $\alpha /$ corepressor complexes were detected by PLA in control and MRTFA- $\triangle$ N200 MCF7 cells treated $48 \mathrm{~h}$ with tetracycline and stimulated or not with $10 \mathrm{nM}$ E2 during $60 \mathrm{~min}$. PLA was performed using ER $\alpha$, SMRT and NCOR1 specific antibodies. Representative pictures of these experiments are shown with dapistained nuclei. Quantification of the number of dots/cell and dots/nucleus was performed using Image J software and was then expressed as a percentage of the number of dots/cell measured in untreated control MCF7 cells. The respective proportion of complex/dots in the nucleus and in the cytoplasm is shown. Values represent the mean $+/-$ SEM. Columns with different superscripts differ significantly ( $\mathrm{n}=30$ to $40 ; \mathrm{P}<0.05$, student 's $t$-test).

Fig. 5. Expression of MRTFA- $\Delta$ N200 protein in MCF7 impacts the dynamic of ERa interaction with kinases. (A), ER $\alpha /$ src and $E R \alpha / P I 3 K$ interactions were detected by PLA in control and MRTFA- $\triangle$ N200 MCF7 cells treated $48 \mathrm{~h}$ with tetracycline and stimulated or not with $10 \mathrm{nM}$ E2 during $10 \mathrm{~min}$. The quantification of the number of dots/cell performed using ImageJ software is shown. Values represent the mean $+/$ - SEM and are expressed as a percentage of the number of dots/cell measured in untreated control MCF7 cells. Columns with different superscripts differ significantly ( $\mathrm{n}=15$ to $50 ; \mathrm{P}<0.05$, student 's $t$-test). (B), The ER $\alpha$ mRNA expression level in MCF7 cells after transfection with control or ER $\alpha$ siRNAs and treated or not with $10 \mathrm{nM}$ E2 or 100 $\mathrm{nM}$ ICI during $24 \mathrm{~h}$ was quantified using real-time PCR. Columns with * differ significantly from the control (untreated MCF7 cells transfected with control siRNA) ( $<<0.01$, student 's $t$-test). (C), Western blot analysis of ER $\alpha$, phospho-ERK (pERK), ERK, phospho-AKT (pAKT), AKT and $\beta$ actin expression in control and MRTFA- $\triangle$ N200 MCF7 after $48 \mathrm{~h}$ tetracyclin treatment and transfection with control or ER $\alpha$ siRNAs. Cells were treated with $10 \mathrm{nM} \mathrm{E2,} 100 \mathrm{nM}$ ICI or vehicle during the last $24 \mathrm{~h}$. (D), Histograms represent the mean $+/-$ SEM of $\mathrm{pER} / \mathrm{ERK}$ or $\mathrm{pAKT} / \mathrm{AKT}$ ratios from three separate experiments. Results were expressed as a percentage of the intensity measured in MRTFA- $\triangle$ N200 MCF7 cells treated with control siRNA and vehicle. Columns with different superscripts differ significantly $(\mathrm{P}<0.05$, student 's $t$-test $)$. 
A

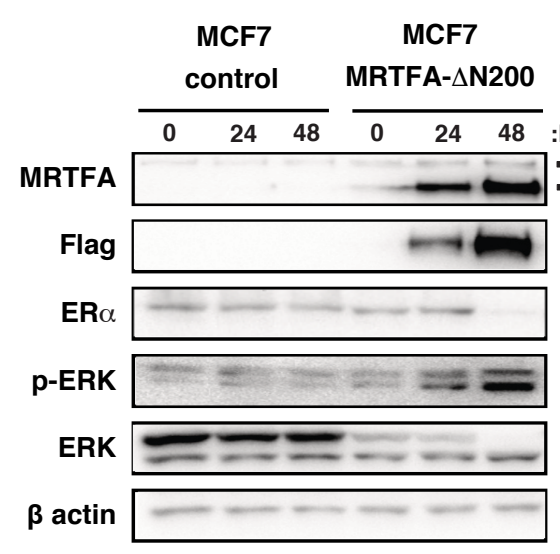

D

$\begin{array}{ccc}\begin{array}{c}\text { MCF7 } \\ \text { control }\end{array} & \begin{array}{c}\text { MCF7 } \\ \text { MRTFA- } \Delta \text { N200 }\end{array} \\ \frac{\mathrm{C}}{\mathrm{E} 2-} \frac{\mathrm{N}}{\mathrm{E} 2-} & \frac{\mathrm{C}}{\mathrm{E} 2-} \frac{\mathrm{N}}{\mathrm{E} 2-}\end{array}$

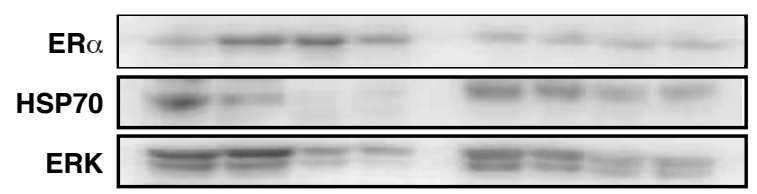

a tubulin

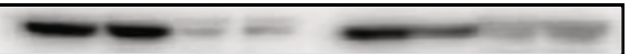

Lamin C

E
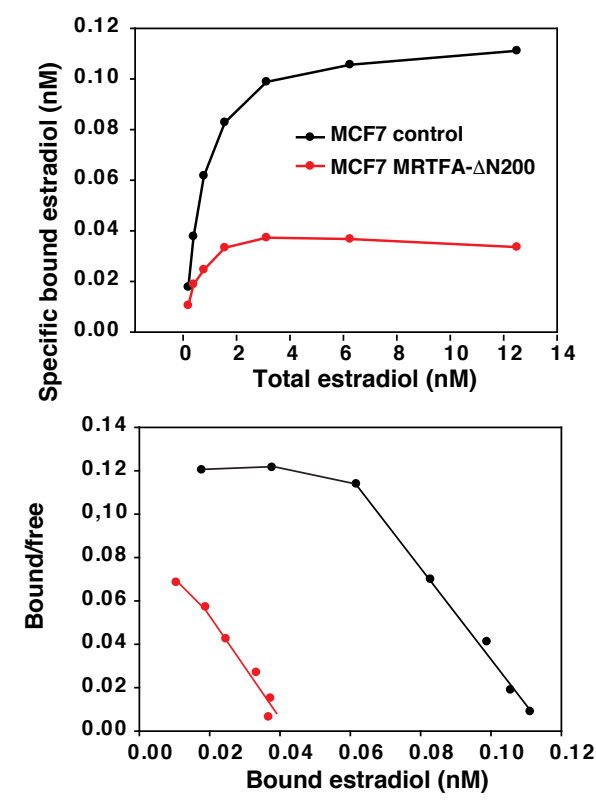

B
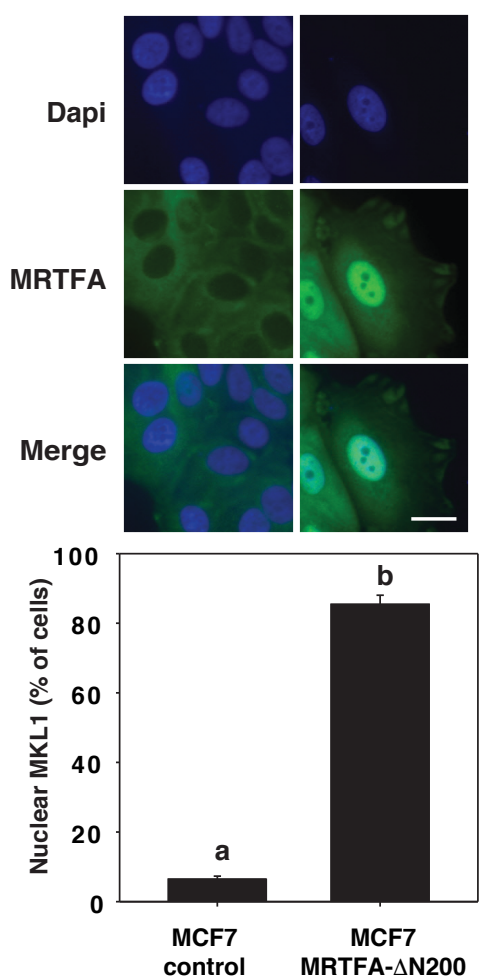

F
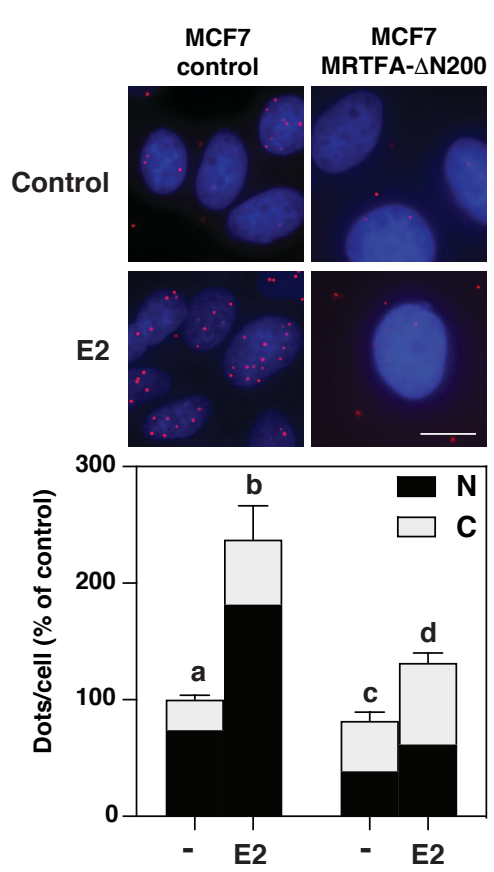

C

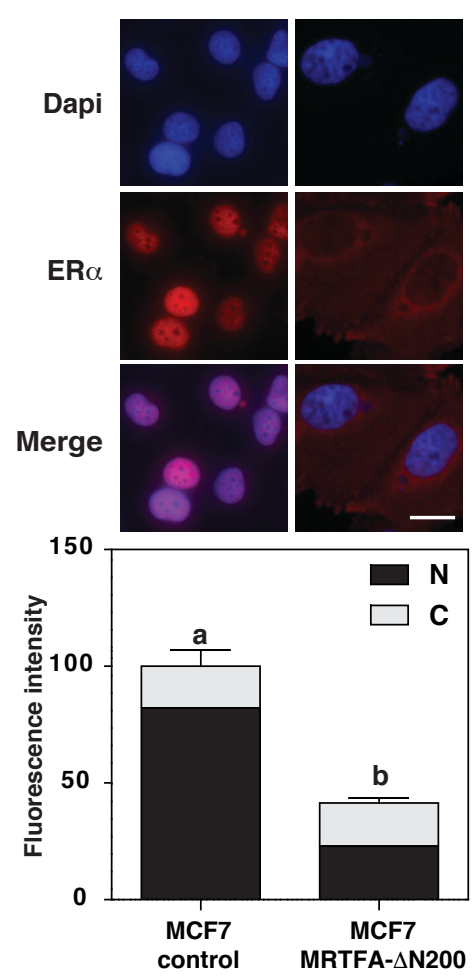

G

ER $\alpha / H S P 70$
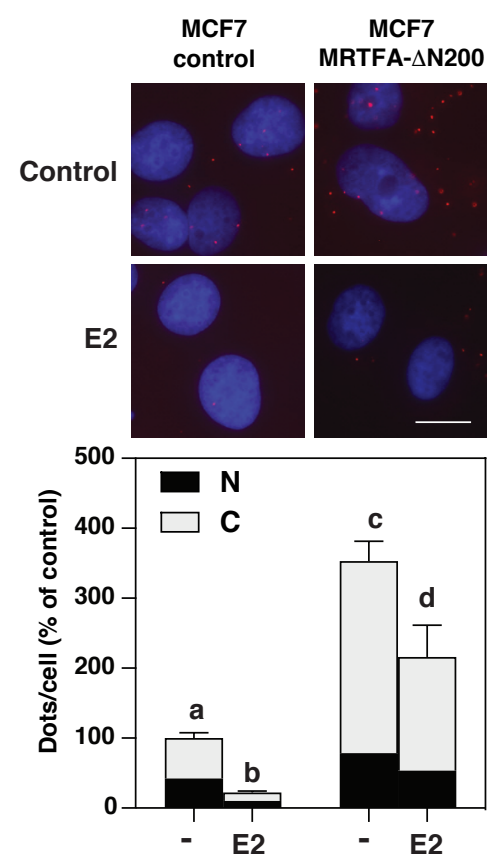
A

Venn

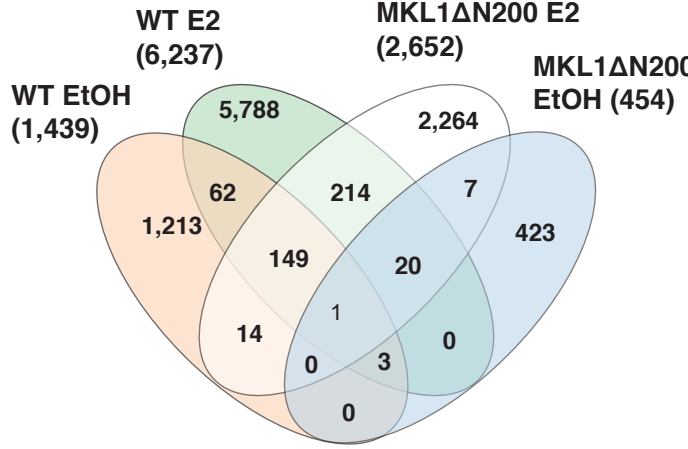

B

CentDist Motifs (Top20)

\begin{tabular}{|c|c|c|c|c|c|c|c|c|c|c|c|}
\hline \multicolumn{6}{|c|}{ WT } & \multicolumn{6}{|c|}{ MKL1 1 N200 } \\
\hline \multicolumn{3}{|c|}{ EtOH } & \multicolumn{3}{|c|}{ E2 } & \multicolumn{3}{|c|}{ EtOH } & \multicolumn{3}{|c|}{ E2 } \\
\hline Family & Score & $P$-value & Family & Score & P-value & Family & Score & P-value & Family & Score & P-value \\
\hline ERE & 33.8812 & 0 & $E R E$ & 52.7692 & 0 & $\mathrm{BACH}$ & 4.73979 & $8.52 e-6$ & ERE & 42.9262 & 0 \\
\hline EBOX & 12.1117 & $1.25 \mathrm{e}-9$ & $A P 1$ & 8.00643 & $3.51 \mathrm{e}-7$ & $A P 1$ & 3.57965 & 0.00027 & $A P 1$ & 7.82989 & $2.0 \mathrm{e}-11$ \\
\hline AP4 & 11.6952 & $4.71 e-9$ & AP4 & 7.92079 & $4.8 \mathrm{e}-7$ & MEIS1 & 3.51415 & 0.000322 & $\mathrm{BACH}$ & 6.70782 & $1.31 \mathrm{e}-8$ \\
\hline HEN & 10.8035 & $6.87 \mathrm{e}-8$ & CREB & 7.23523 & $5.12 \mathrm{e}-6$ & STAT & 2.93711 & 0.00137 & NRF & 6.00369 & $4.46 e-7$ \\
\hline AP2 & 10.549 & $1.42 \mathrm{e}-7$ & EBOX & 7.13292 & $7.15 \mathrm{e}-6$ & EBOX & 2.69213 & 0.00242 & MAF & 5.43218 & $5.8 e-6$ \\
\hline MINI & 9.92837 & $7.73 e-7$ & $S P 1$ & 7.10752 & $7.76 e-6$ & ETS & 2.59513 & 0.00301 & PTF1B & 5.35381 & $8.07 e-6$ \\
\hline$S P 1$ & 8.88496 & $1.06 \mathrm{e}-5$ & CACCC & 6.86973 & $1.65 e-5$ & sox & 2.53176 & 0.00346 & SMAD & 5.24949 & $1.24 \mathrm{e}-5$ \\
\hline WT1 & 8.45179 & $2.87 e-5$ & САССТ & 6.72808 & $2.55 e-5$ & ERE & 2.43844 & 0.00423 & SP1 & 5.09233 & $2.34 \mathrm{e}-5$ \\
\hline CACCC & 8.42427 & $3.06 e-5$ & MAF & 6.68255 & $2.93 e-5$ & AR & 2.2479 & 0.0063 & AR & 4.88613 & $5.23 e-5$ \\
\hline PAX & 8.2947 & $4.08 e-5$ & HEN & 6.36099 & $7.53 e-5$ & MAF & 2.12121 & 0.00812 & EBOX & 4.77781 & $7.86 e-5$ \\
\hline ZNF219 & 7.71718 & 0.00014 & DBP & 6.3558 & $7.65 e-5$ & CAP & 2.051 & 0.00932 & FAC1 & 4.60093 & 0.00015 \\
\hline EGR & 7.53189 & 0.000203 & PAX & 6.27421 & $9.64 e-5$ & CEBP & 2.02953 & 0.00972 & FOX & 4.59252 & 0.000154 \\
\hline CREB & 7.51736 & 0.000209 & TEF & 6.19311 & 0.000121 & HSF & 1.76693 & 0.0159 & ETS & 4.45186 & 0.000253 \\
\hline SMAD & 7.00604 & 0.000562 & AP2 & 5.94409 & 0.000238 & NRF & 1.64101 & 0.0199 & AP4 & 4.42581 & 0.000276 \\
\hline LRF & 6.9071 & 0.000675 & RFX & 5.94098 & 0.00024 & CAAT & 1.62745 & 0.0204 & MEF3 & 4.40044 & 0.000301 \\
\hline $\mathrm{HIC} 1$ & 6.87095 & 0.000722 & SMAD & 5.74923 & 0.000397 & IRF & 1.59808 & 0.0215 & LMAF & 4.28519 & 0.000444 \\
\hline CP2 & 6.8691 & 0.000724 & TGTGGT & 5.58621 & 0.0006 & P53 & 1.56272 & 0.0228 & HEN & 4.27006 & 0.000467 \\
\hline ZID & 6.8283 & 0.00078 & LMAF & 5.48638 & 0.000768 & BRN2 & 1.55481 & 0.0231 & TFIII & 4.24295 & 0.000511 \\
\hline LMAF & 6.41347 & 0.00162 & MEF3 & 5.47791 & 0.000784 & DMRT & 1.54374 & 0.0236 & SRF & 4.22397 & 0.000543 \\
\hline TFIII & 6.09462 & 0.00276 & $\mathrm{CP} 2$ & 5.47629 & 0.000787 & LEF & 1.53806 & 0.0238 & MYOGNF1 & 4.21269 & 0.000564 \\
\hline
\end{tabular}

C

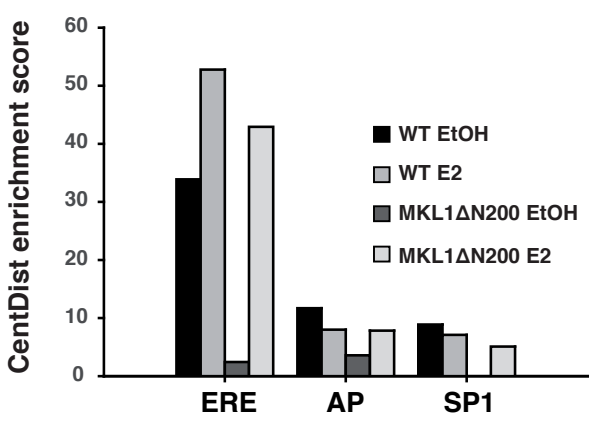

D

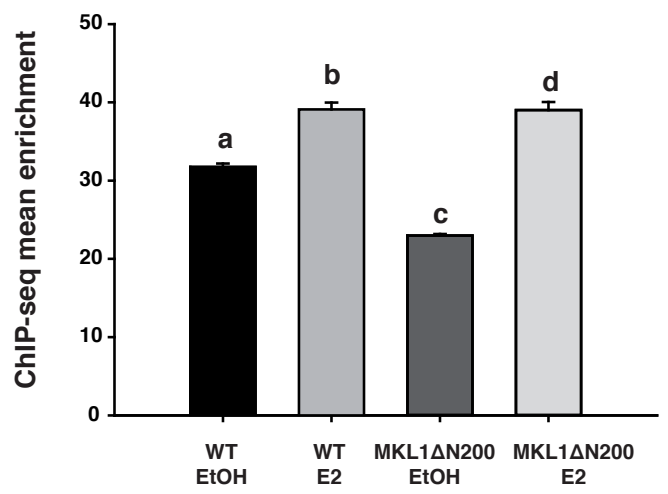


A
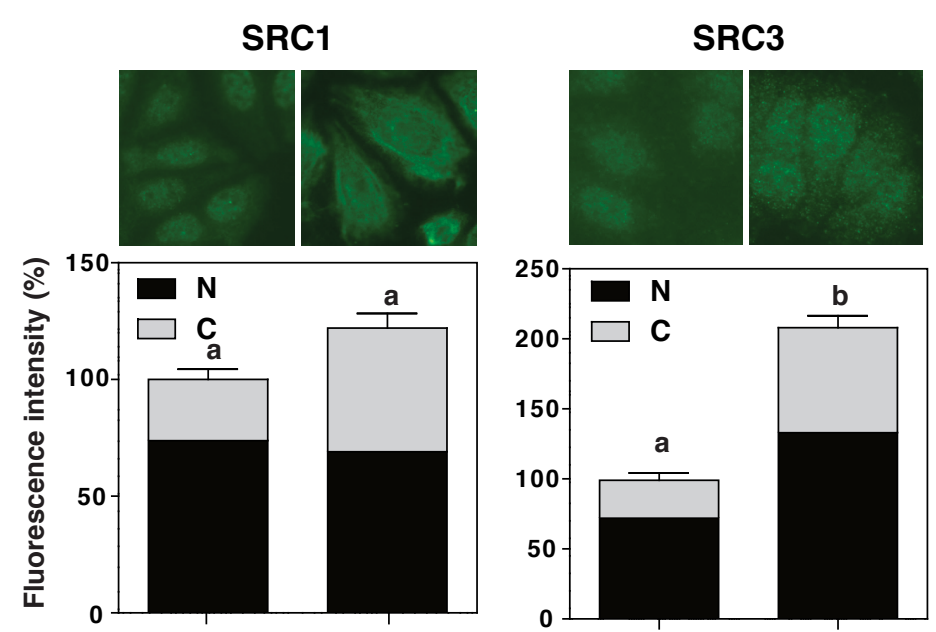

B
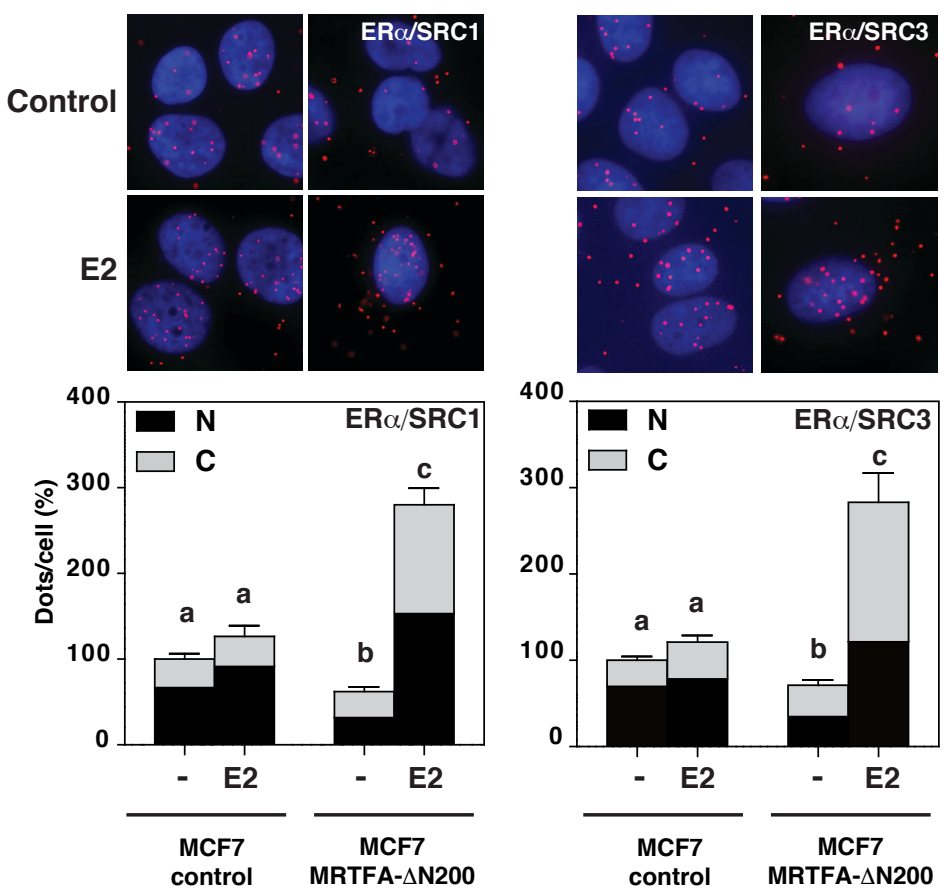
A

SMRT

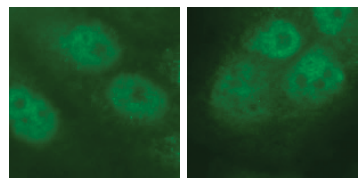

NCOR1
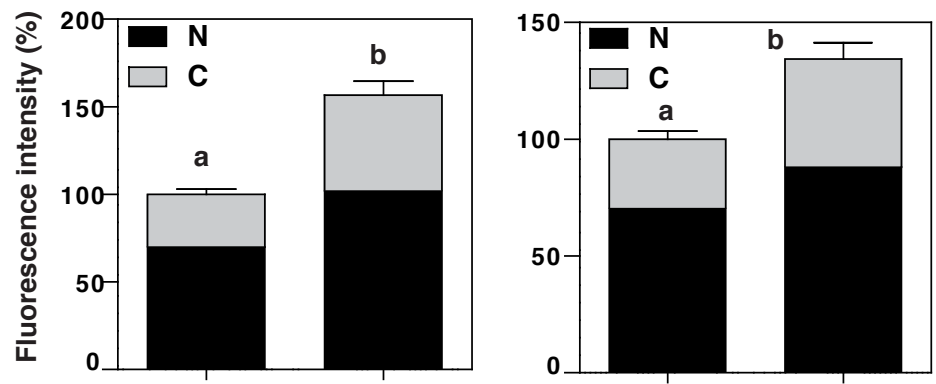

B
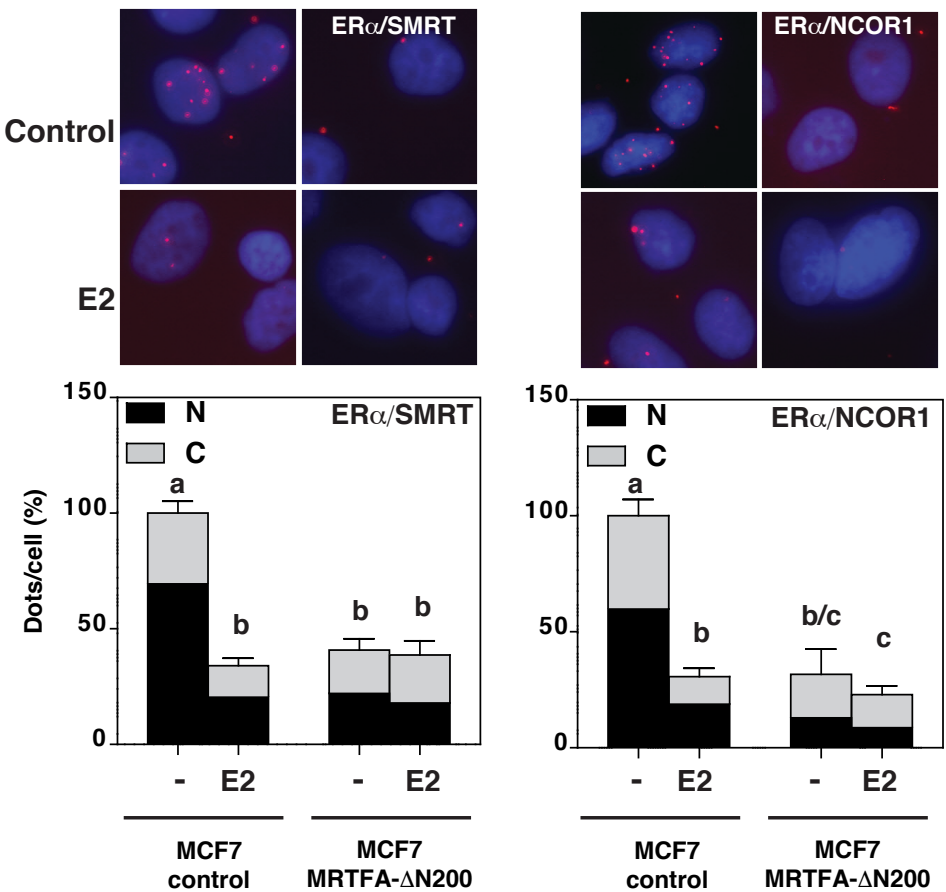
A
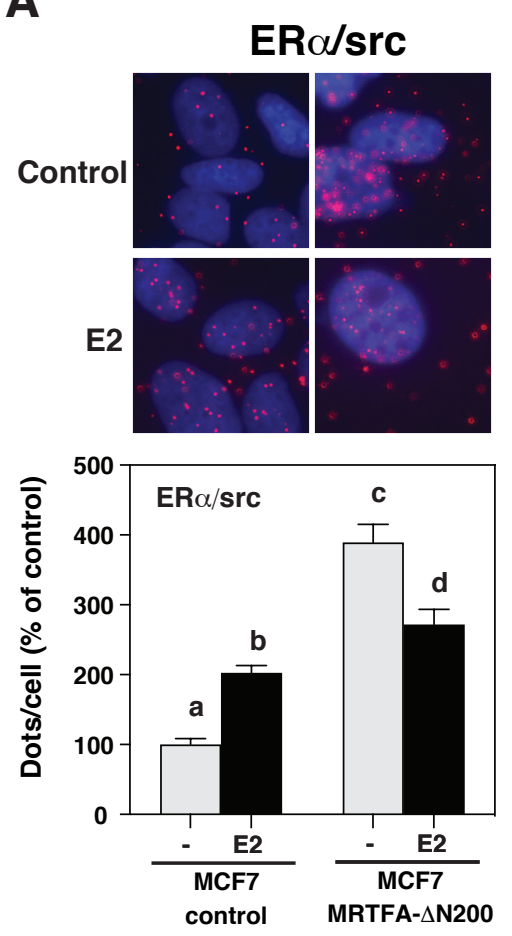

B

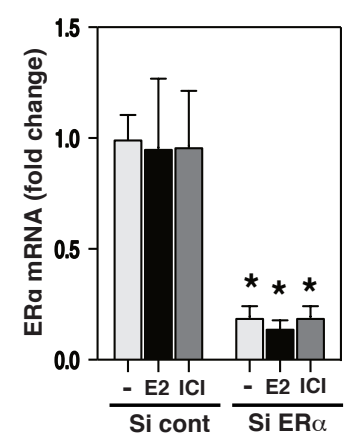

PERK

ERK

PAKT

AKT

$\beta$ actin

\section{ER $\alpha / p 85$ PI3K}
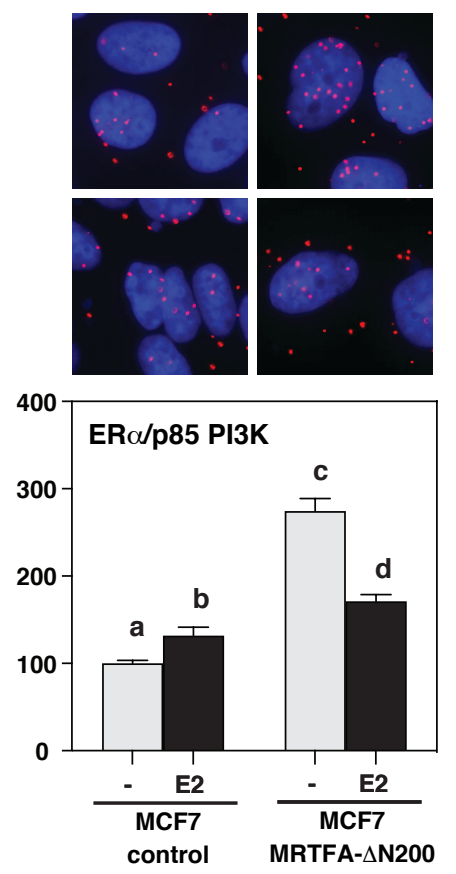

MCF7

MCF7

MRTFA- $\triangle$ N200
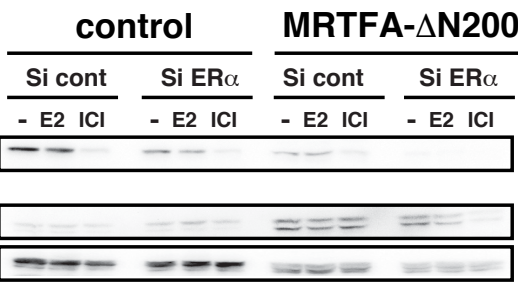

\begin{tabular}{l}
\hline$-1-\cdots-1$ \\
\hline$-\infty-\cdots-\cdots$ \\
\hline
\end{tabular}
D
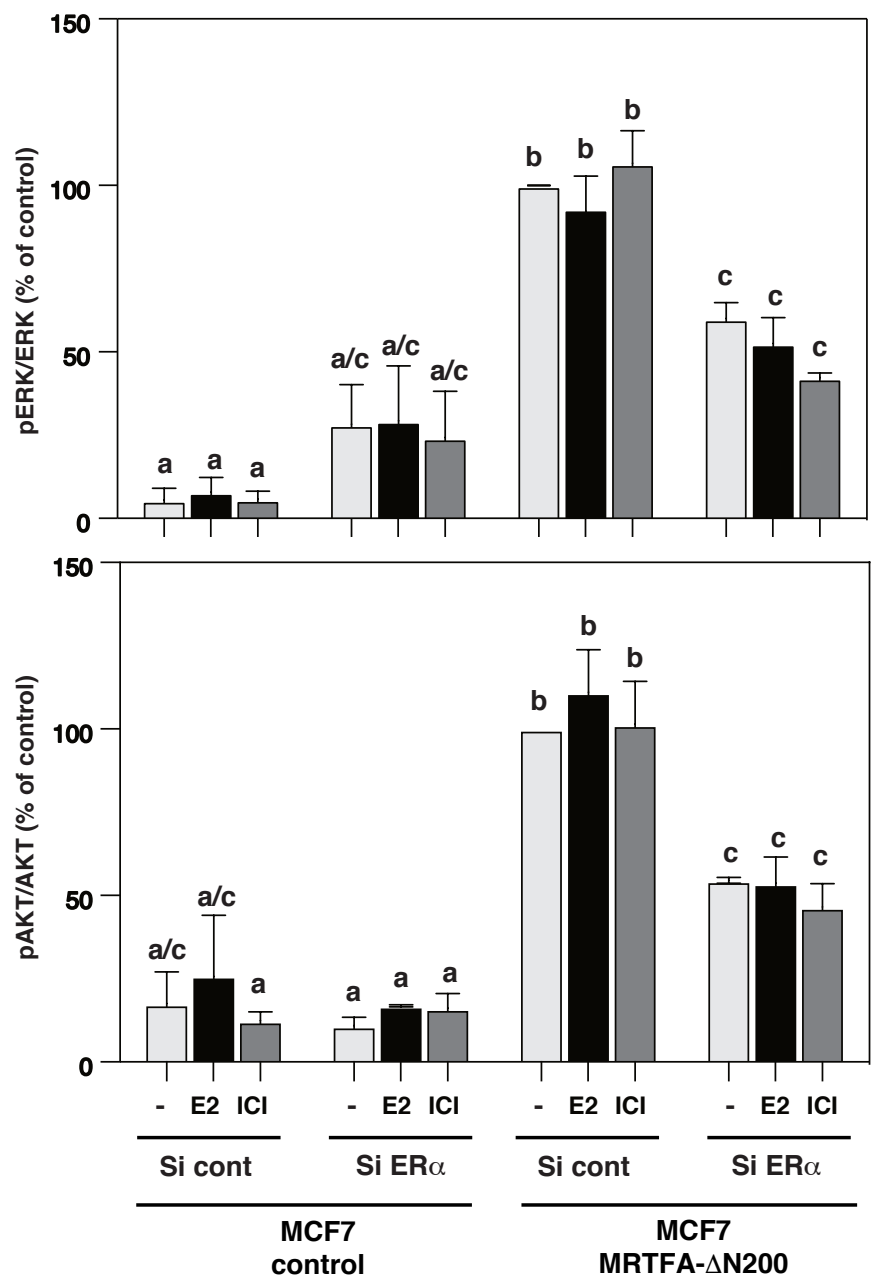
A

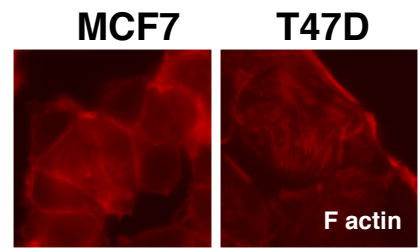

C

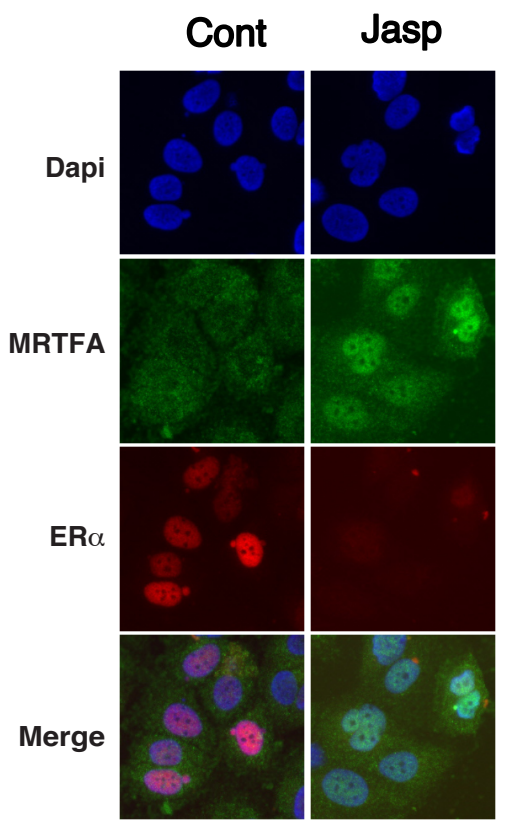

T47D Cont Jasp
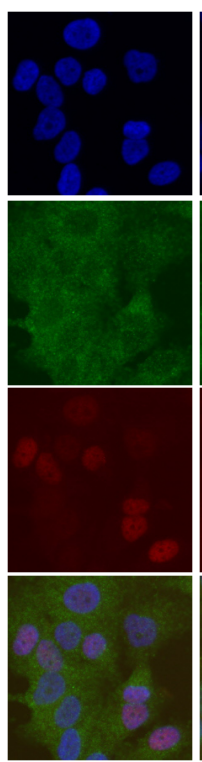
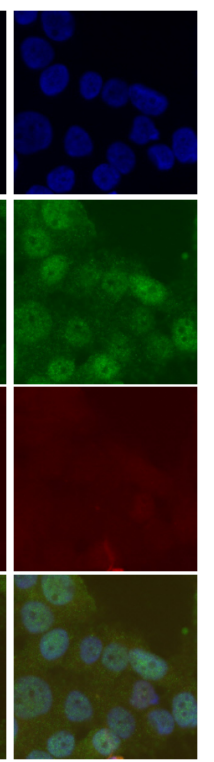

B

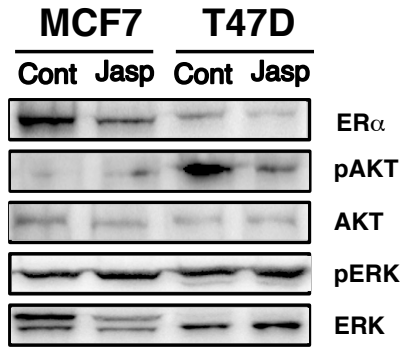

D

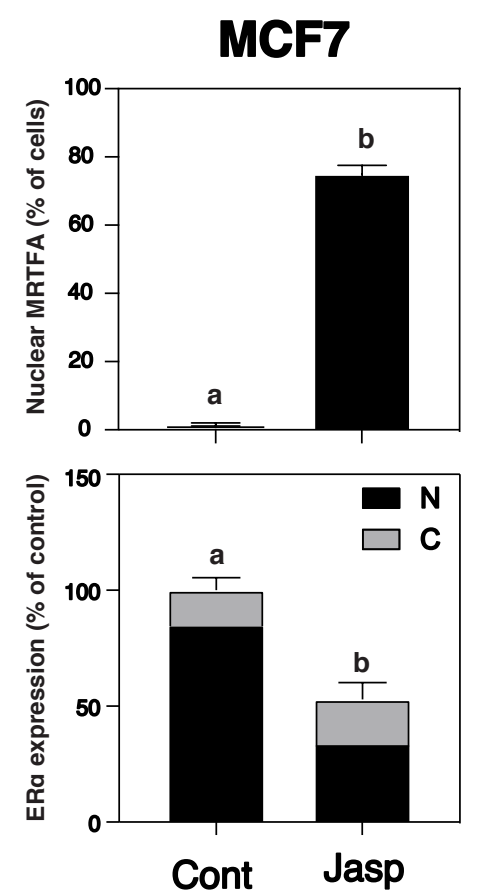

T47D
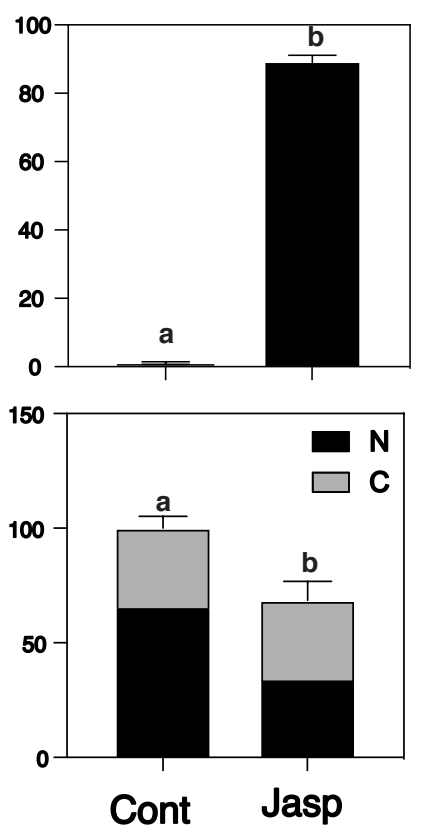

F
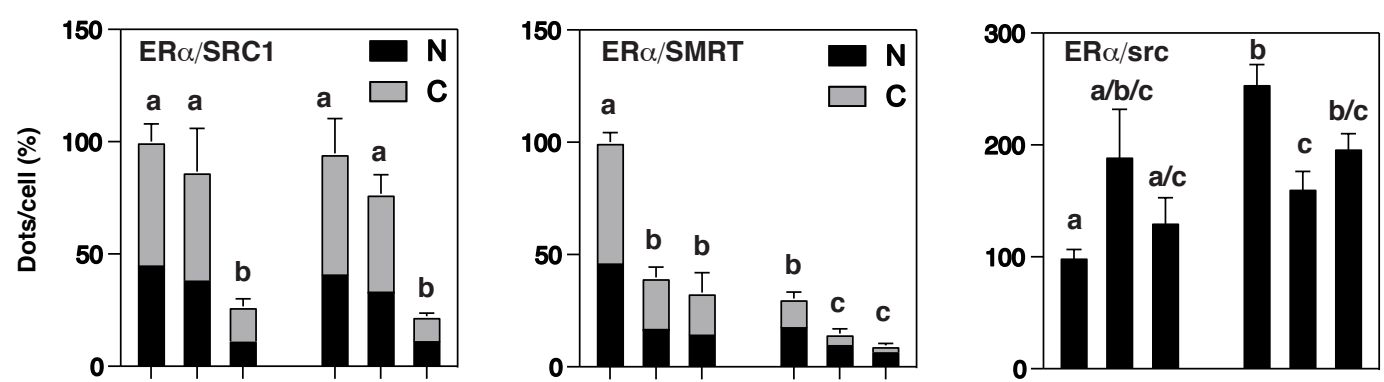

MCF7
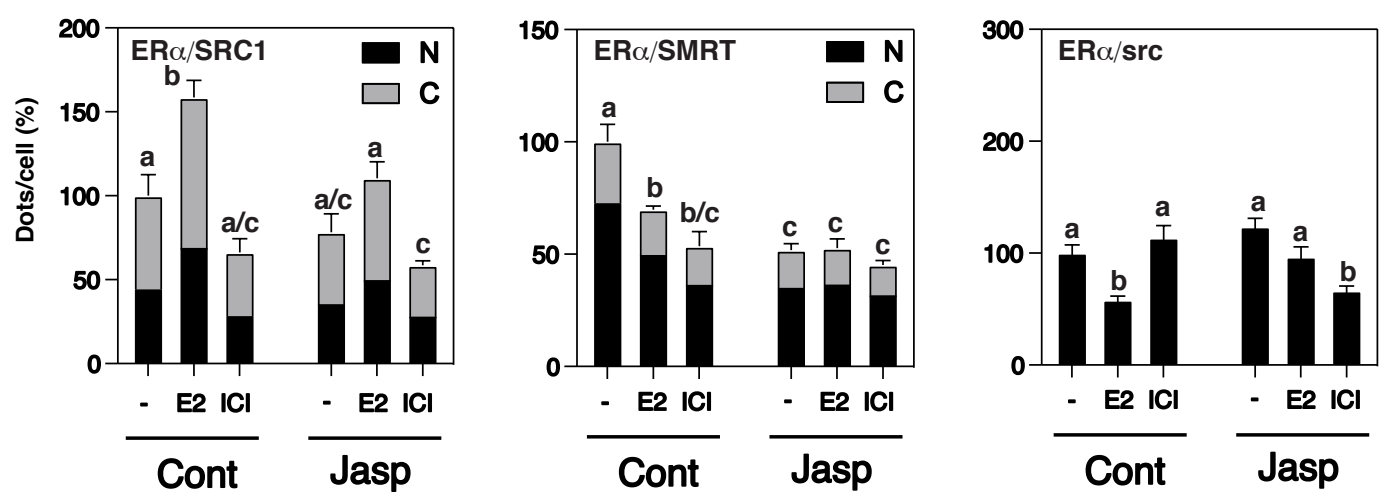

T47D

Supplementary Fig. 1. Effects of jasplakinolide on ERa and MRTFA subcellular localization and on the interaction of ERa with SRC1, SMRT and sre in MCF7 and T47D cells. (A), Immonofluorescent detection of F actin in MCF7 and T47D cells using Alexa Fluor 594 phalloidin. (B), Western blot analysis of ER $\alpha$, phospho-ERK (pERK), and phospho-AKT (pAKT) expression in whole cell extracts of MCF7 and T47D cells. ERK total expression was used as a loading control. (C), immunofluorescent detection of the subcellular localization of ER $\alpha$ and MRTFA in MCF7 and T47D cells treated or not with jasplakinolide $(0.5 \mu \mathrm{g} / \mathrm{ml})$ during $24 \mathrm{~h}$. (D), For MRTFA, the graph represents the percentage of cells with a MRTFA nuclear staining. For ER $\alpha$, the bar chart represents the fluorescence intensity as measured through densitometry quantification, expressed as a percentage of the intensity measured in control MCF7 and T47D cells. The respective proportion of ER $\alpha$ nuclear and cytoplasmic staining is indicated. Error bars represent SEM ( $\mathrm{n}=10 ; \mathrm{P}<0.01$, student 's t-test). (F), ER $\alpha / \mathrm{SRC} 1$, ER $\alpha /$ SMRT and ER $\alpha /$ src interactions were detected by PLA in MCF7 and T47D cells treated 24h or not with jasplakinolide $(0.5 \mu \mathrm{g} / \mathrm{ml})$ and stimulated or not with $10 \mathrm{nM} \mathrm{E} 2$ or $100 \mathrm{nM}$ ICI 182,780 (ICI) during the last $1 \mathrm{~h}$ (ER $\alpha / \mathrm{SRC} 1$, ER $\alpha / \mathrm{SMRT}$ interactions) or the last $10 \mathrm{~min}$ (ER $\alpha / \mathrm{src}$ interaction). Quantification of the number of dots/cell was performed using ImageJ software. The respective proportion of complex/dots in the nucleus and in the cytoplasm is shown for ER $\alpha / \mathrm{SRC} 1$ and $\mathrm{ER} \alpha /$ SMRT interactions. Values are expressed in percentage to the control (untreated MCF7 and T47D cells) and represent

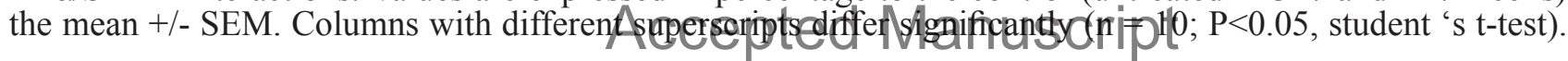




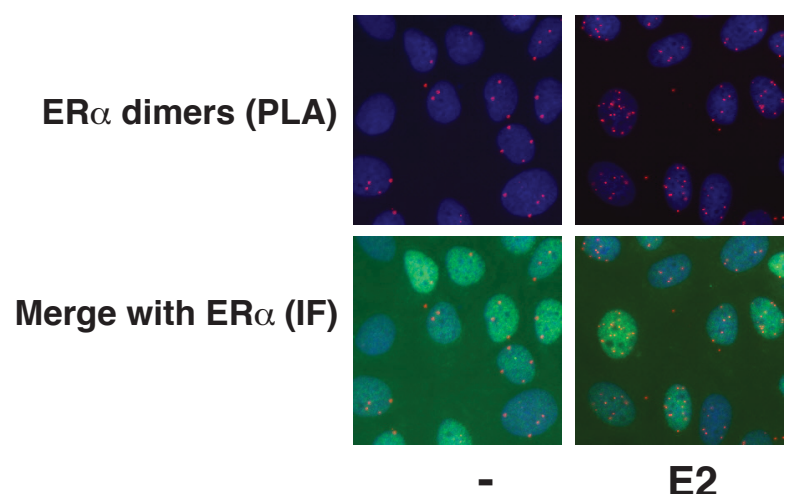

B

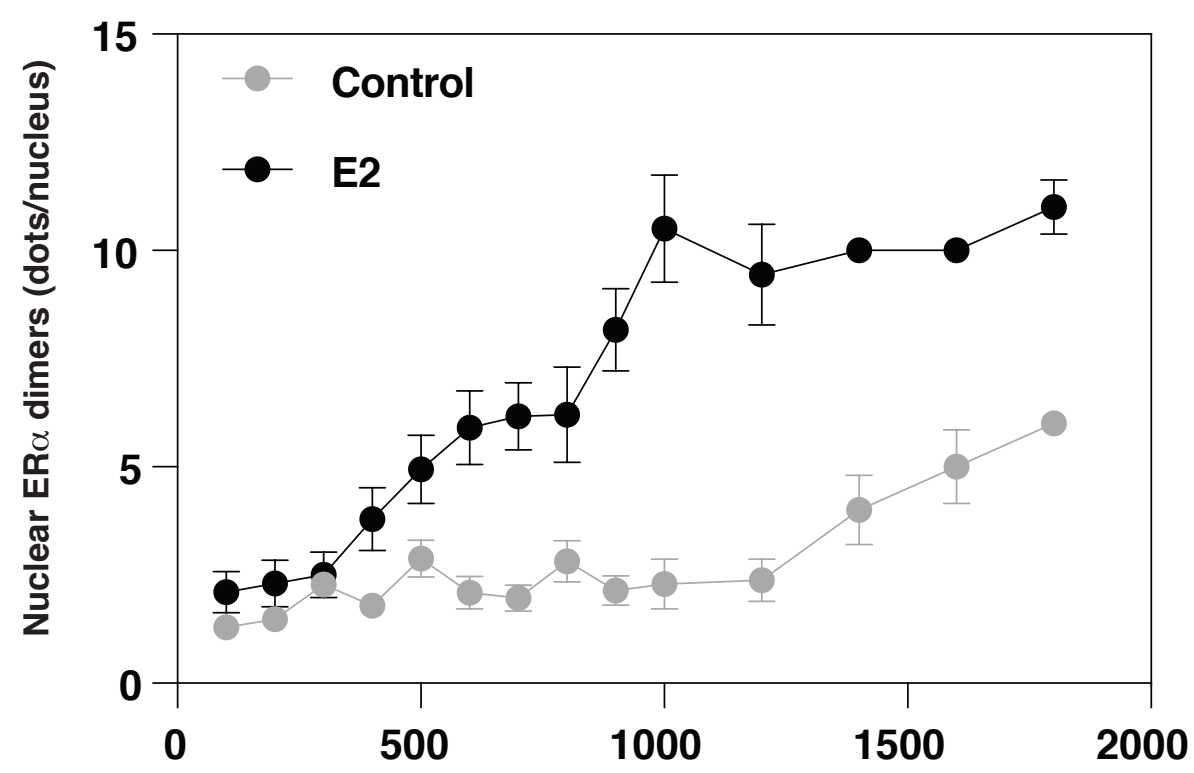

Nuclear ER $\alpha$ level (arbitrary unit)

Supplementary Fig. 2. In situ detection of endogenous ER $\alpha$ dimer complex in MCF7 cells by PLA assays. (A), $\mathrm{ER} \alpha$ dimers were detected by PLA in MCF7 cells treated or not with $10 \mathrm{nM}$ E2 during $60 \mathrm{~min}$. PLA was performed using an ER $\alpha$ monoclonal antibody (sp1) directly conjugated to the PLA MINUS and PLUS oligonucleotides, as described in the Materials and Methods section of the main manuscript. The detected dimers are represented by red dots. In parallel, ER $\alpha$ staining was visualized by immunofluorescence on the same coverslip. (B), The graph shows the number of detected nuclear dimer/dots, expressed as a function of the intensity of the ER $\alpha$ nuclear staining by cell. Quantifications of the number of dots/cell and the ER $\alpha$ nuclear staining were performed using ImageJ software on 350 cells. Cells were classified according to the relative intensity of ER $\alpha$ staining and grouped in intensity window every 100 units. The number of dots per cell was then averaged for a given intensity window. Values represent the mean $+/-$ SEM. 
A

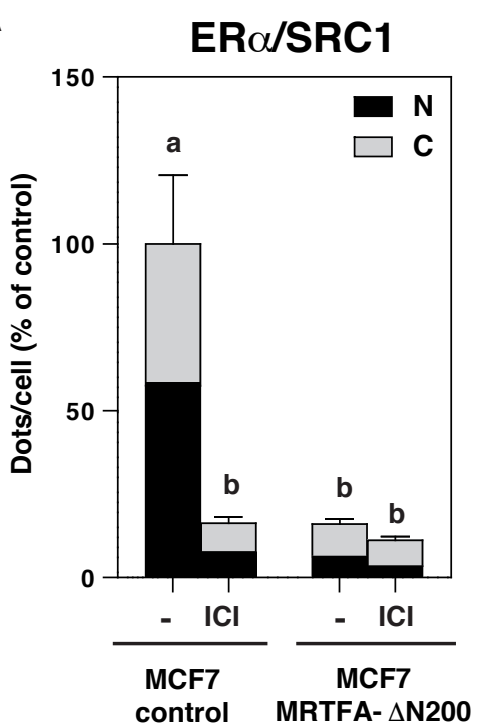

B

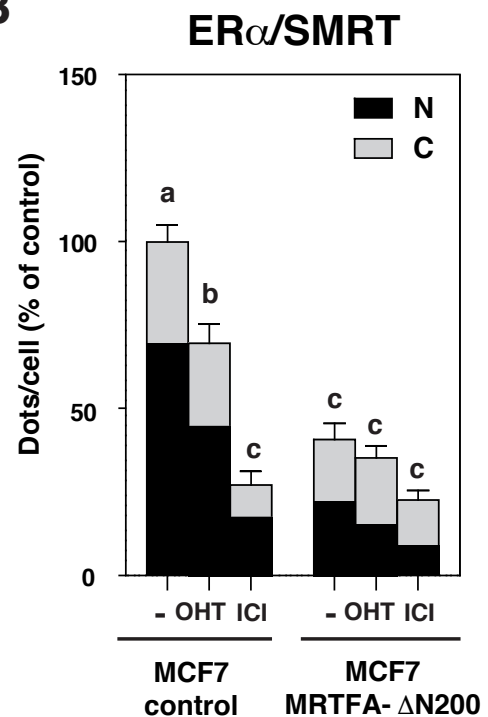

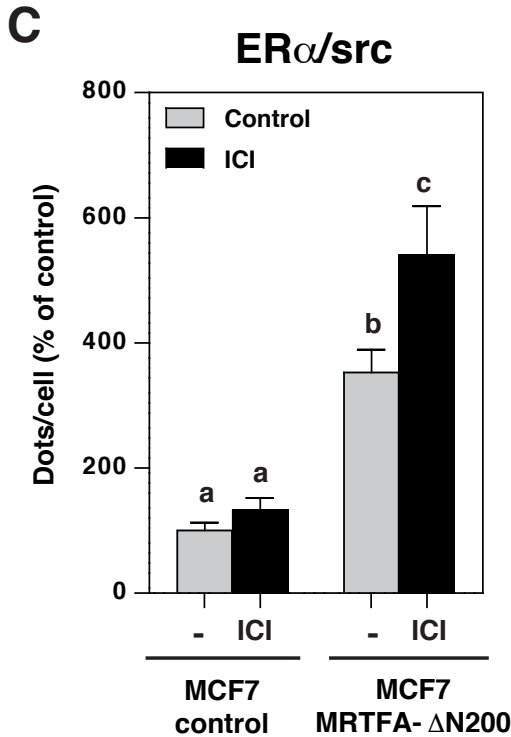

Supplementary Fig. 3. Effects of ER $\alpha$ antagonists on the interaction of ER $\alpha$ with SRC1, SMRT and src in control and MRTFA- $\triangle$ N200 MCF7 cells. (A), (B) and (C), ER $\alpha / S R C 1, E R \alpha / S M R T$ and ER $\alpha /$ src interactions were detected by PLA in control and MRTFA- $\triangle$ N200 MCF7 cells which were treated 48h with tetracyclin and stimulated or not with $100 \mathrm{nM}$ ICI 182,780 (ICI) or $1 \mu \mathrm{M}$ 4-hydroxytamoxifen $(\mathrm{OHT})$ during the last $1 \mathrm{~h}(\mathrm{ER} \alpha / \mathrm{SRC} 1, \mathrm{ER} \alpha / \mathrm{SMRT}$ interactions) or the last 10 $\min (E R \alpha /$ src interaction). Quantification of the number of dots/cell was performed using ImageJ software. The respective proportion of complex/dots in the nucleus and in the cytoplasm is shown for ER $\alpha / \mathrm{SRC} 1$ and ER $\alpha / \mathrm{SMRT}$ interactions. Values are expressed in percentage to the control (untreated MCF7 control cells) and represent the mean +/- SEM. Columns with different superscripts differ significantly ( $\mathrm{n}=20$ to $30 ; \mathrm{P}<0.01$, student 's t-test).

A

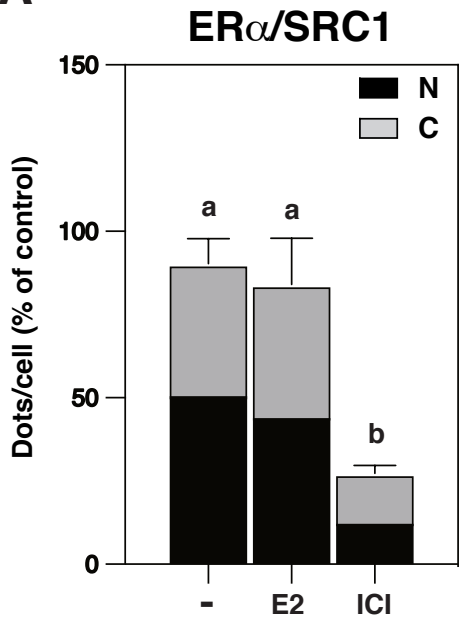

B

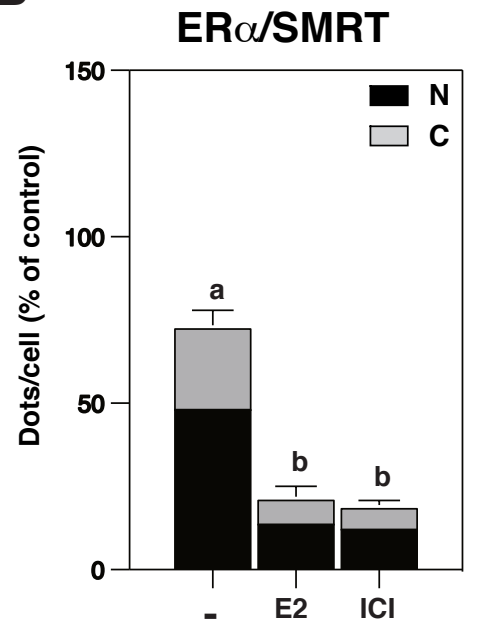

C

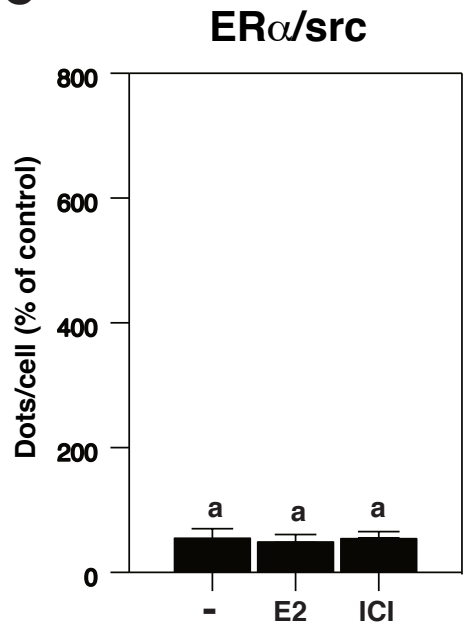

Supplementary Fig. 4. Interaction of ER $\alpha$ with SRC1, SMRT and src in MRTFA- $\Delta$ N200 MCF7 cells in the absence of induction of MRTFA- $\Delta$ N200 expression. (A), (B) and (C), ER $\alpha / \mathrm{SRC} 1, \mathrm{ER} \alpha / \mathrm{SMRT}$ and $\mathrm{ER} \alpha / \mathrm{src}$ interactions were detected by PLA in Control and MRTFA- $\triangle$ N200 MCF7 cells treated or not with $10 \mathrm{nM}$ E2 or $100 \mathrm{nM}$ ICI 182,780 (ICI) during the last $1 \mathrm{~h}(\mathrm{ER} \alpha / \mathrm{SRC} 1, \mathrm{ER} \alpha / \mathrm{SMRT}$ interactions) or the last $10 \mathrm{~min}(\mathrm{ER} \alpha / \mathrm{src}$ interaction). Cells were not treated with tetracyclin. Quantification of the number of dots/cell was performed using ImageJ software. The respective proportion of complex/dots in the nucleus and in the cytoplasm is shown for ER $\alpha / \mathrm{SRC} 1$ and ER $\alpha / \mathrm{SMRT}$ interactions. Values are expressed in percentage to the control (untreated MCF7 control cells) and represent the mean +/- SEM. Columns with different superscripts differ significantly ( $\mathrm{n}=10$ to $20 ; \mathrm{P}<0.01$, student 's t-test). 